\title{
A REVIEW ON ANTIOXIDANT METHODS
}

\author{
SUNITHA DONTHA* \\ Department of Pharmaceutical Chemistry, Malla Reddy College of Pharmacy, Maisammaguda, Secunderabad, Telangana, India. \\ Email: chmrcp@gmail.com
}

Received: 26 May 2016, Revised and Accepted: 28 June 2016

\section{ABSTRACT}

To provide an outlook of the various available methods of antioxidant activity. Various available in vitro and in vivo methods are listed and the procedure to perform the method, its mechanism is also explained in brief. 1,1-diphenyl-2-picrylhydrazyl method was found to be used mostly for the in vitro antioxidant activity evaluation purpose while lipid peroxidation was found as mostly used in vivo antioxidant assay. An ethanol was with the highest frequency as a solvent for extraction purpose. Summarized information on the various methods available provides with reliable information to confirm the benefits of antioxidant effects.

Keywords: Antioxidant activity, Reactive oxygen species, Free radical, 1,1-diphenyl-2-picrylhydrazyl, Flavonoid.

(c) 2016 The Authors. Published by Innovare Academic Sciences Pvt Ltd. This is an open access article under the CC BY license (http://creativecommons. org/licenses/by/4. 0/) DOI: http://dx.doi.org/10.22159/ajpcr.2016.v9s2.13092

\section{INTRODUCTION}

Antioxidants became a vital part of our lives today since antioxidants neutralizes or destroys "reactive oxygen species" (ROS) or free radicals before they damage cells. The oxidation induced by ROS results in cell membrane disintegration, membrane protein damage, and DNA mutations, which results in aging and further initiates or propagates the development of many diseases such as arteriosclerosis, cancer, diabetes mellitus, liver injury, inflammation, skin damages, coronary heart diseases, and arthritis.

The chemical compounds, which decrease the rate of lipid oxidation reaction in food systems, are called antioxidants. By definition, a substance that opposes oxidation or inhibits reactions promoted by oxygen or peroxides; many of these substances being used as preservatives in various products are antioxidants. Biologically antioxidants are defined as synthetic or natural substances added to products to prevent or delay their deterioration by the action of oxygen in air. For example, enzymes or other organic substances such as vitamin $\mathrm{E}$ or $\beta$-carotene.

Antioxidants are chemical compounds which bind to free oxygen radicals and prevents these radicals from damaging healthy cells.

This review focuses mainly on the types of damaging free radicals generated in metabolic processes and also gives an insight of mechanistic aspect of various in vitro and in vivo methods for the evaluation of antioxidant capacity (Fig. 1).

By the normal use of oxygen [1], free radicals are produced continuously by the body. Oxygen is an element indispensable for life. When cells use oxygen to generate energy, free radicals are produced by the mitochondria. These by-products are generally ROS as well as reactive nitrogen species (RNS) that result from the cellular redox process. The free radicals have a special affinity for lipids, proteins, carbohydrates, and nucleic acids [2].

A free radical is a chemical species, capable of independent existence possessing one or more unpaired electron. The free radicals are less stable than non-radicals and are capable of reacting indiscriminately with molecules. Once radicals are formed, they can either react with another radical or with another non-radical molecule by various interactions. When two radicals collide with their unpaired electron, forms a covalent bond. The most molecules found in vivo are non- radicals. A radical donates its unpaired electron to the other molecules, or takes one electron from it, thus transforming its radical character. At the same time, a new radical is formed $[3,4]$. ROS/RNS are present in the atmosphere as pollutants and can be generated (i) during ultraviolet (UV) light irradiation, by X-rays and gamma rays; (ii) during metal catalyzed reactions; (iii) by neutrophils, esinophils and macrophages during inflammatory cell activation [5,6]; (iv) as by-products of mitochondrial catalyzed electron transport reactions; (v) by cytochrome P450 metabolism and the enzyme xanthine oxidase, which catalyzes the reaction of hypoxanthine to xanthine and xanthine to uric acid [7]

Depending on the environment and concentration of ROS, it is both harmful and beneficial in biological systems [8,9]. For example, the physiological roles in cellular responses to noxia such as defense against infectious agents, and in the function of a number of cellular signaling systems and gene expression. In contrast, at high concentrations, ROS mediates damage to cell structures including lipids and membranes, proteins, and nucleic acids; which is known as "oxidative stress" [10].

Oxidative stress is defined as an imbalance between the production of free radicals and reactive metabolites, so-called oxidants or ROS, and their elimination by protective mechanisms referred to as antioxidants. This imbalance leads to damage of important biomolecules and cells, with potential impact on the whole organism [11]. The harmful effects of ROS are balanced by the action of antioxidants, example like enzymes present in the body [12]. Despite the presence of the cell's antioxidant defense system to counteract oxidative damage from ROS, oxidative damage accumulates during the life cycle and has been implicated in diseases, aging and age-dependent diseases such as cardiovascular disease, cancer, neurodegenerative disorders, and other chronic conditions [13].

ROS is classified into oxygen-centered radicals and oxygen-centered non-radicals.

i. Oxygen-centered radicals are superoxide anion $\left(\cdot \mathrm{O}_{2}^{-}\right)$, hydroxyl radical $(\cdot \mathrm{OH})$, alkoxyl radical (RO·), and peroxyl radical (ROO·). Other reactive species are nitrogen species such as nitric oxide (NO·), nitric dioxide $\left(\mathrm{NO}_{2}\right)^{-}$), and peroxynitrite (OONO-).

ii. Oxygen-centered non-radicals are hydrogen peroxide $\left(\mathrm{H}_{2} \mathrm{O}_{2}\right)$ and singlet oxygen $\left({ }^{1} \mathrm{O}_{2}\right)$, hypochlorous acid and ozone $[14,15]$.

ROS, which consist of free radicals such as superoxide anion $\left(\mathrm{O}_{2}^{-}\right)$ and hydroxyl (HO-) radicals and non-free radical species, such as $\mathrm{H}_{2} \mathrm{O}_{2}$ and singled oxygen $\left(\mathrm{O}_{2}\right)$, are different forms of activated oxygen. 
ROS are produced by all aerobic organisms and can easily react with most biological molecules including proteins, lipids, lipoproteins, and DNA. Thus, the generation of ROS proceeds to a variety of pathophysiological disorders such as arthritis, diabetes, inflammation, cancer, and genotoxicity. Therefore, living organisms possess a number of protective mechanisms against the oxidative stress and toxic effects of ROS. Antioxidants regulate various oxidative reactions naturally occurring in tissues. Furthermore, terminates or retards the oxidation process by scavenging free radicals, chelating free catalytic metals and also by acting as electron donors.

A diet high in foods of animal origin and saturated fats increases the risk of cardiovascular diseases and some cancers [16], which has generated interest in promoting the consumption of plant-derived proteins $[17,18]$. Legumes such as cereals, fruits, and vegetables have health-promoting compounds and nutritional value [19]. The nutritional quality and nutraceutical content associated with the antioxidant activity of legumes such as common bean are important sources of nutritional components (proteins, carbohydrates, fiber, vitamins, and some minerals) $[20,21]$.

Hence legumes are considered as nutraceutical food, due to the presence of wide variety of phytochemicals such as phenolic compounds, flavonoids, tannins, and unsaturated fatty acids. Nutraceutical foods are preferred because they prevent degenerative diseases and maintain good health [22]. From the epidemiological and pharmacological evidence, it was found that nutraceutical properties of active compounds in edible plants have increased, contribution for the prevention and reduction of heart disease, diabetes, hypertension, Alzheimer's disease and arteriosclerosis, etc. [23-26].

\section{ROLE OF ANTIOXIDANTS}

An antioxidant is a molecule capable of inhibiting the oxidation of another molecule. It breaks the free radical chain of reactions by sacrificing their own electrons to feed free radicals, without becoming free radicals themselves (Fig. 2).

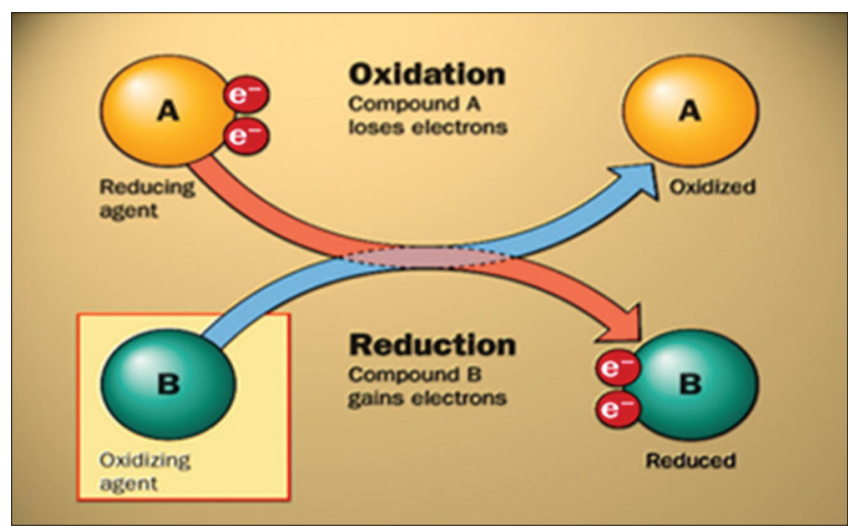

Fig. 1: Oxidation and reduction process

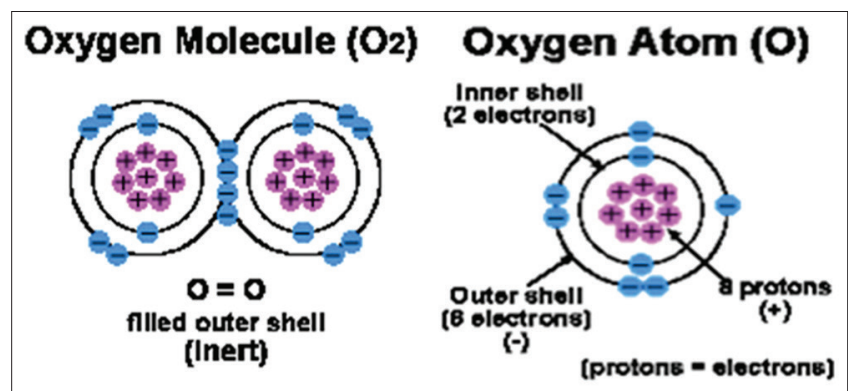

Fig. 2: Electrons in the outer shell

\section{ANTIOXIDANTS PREVENTS AGAINST FREE RADICAL DAMAGE}

Antioxidants are nature's way of defending cells against attack by ROS. Our body naturally circulates a variety of nutrients for their antioxidant properties and manufactures antioxidant enzymes to control these destructive chain reactions. Forexample, vitamin C, vitamin E, carotenes, and lipoic acid.

Oxidative stress is defined as the state in which the free radicals in the body outnumber our antioxidant defenses. They also decrease the telomere length of the chromosome (Fig. 3).

Oxidation is a chemical reaction that transfers electrons from a substance to an oxidizing agent. Free radicals produced by these oxidation reactions, start chain reactions that damage cells. Antioxidants terminate these chain reactions by removing free radical intermediates and inhibit other oxidation reactions by being oxidized themselves. Hence, antioxidants are often reducing agents like thiols or polyphenols.

Oxidation reactions are important for life, but they are also damaging cells. Hence, plants and animals maintain complex systems of multiple types of antioxidants such as glutathione (GSH), vitamin C, and vitamin E as well as enzymes such as catalase (CAT), superoxide dismutase (SOD), and various peroxidases. Low levels of antioxidants, or inhibition of antioxidant enzymes, causes oxidative stress and damages or kill cells.

These oxidants damage cells by chain reactions such as lipid peroxidation (LPO), or by oxidizing DNA or proteins. Damage to DNA causes mutations and possibly cancer, if not reversed by DNA repair mechanisms, while damage to proteins causes enzyme inhibition, denaturation and protein degradation. The brain is vulnerable to oxidative injury, by LPO due to its high metabolic rate and elevated levels of polyunsaturated lipids. Antioxidants prevent oxidative stress in neurons and prevent apoptosis and neurological damage [27-29].

\section{CLASSIFICATION OF ANTIOXIDANTS}

Antioxidants can be categorized into two types.

\section{Non-enzymatic antioxidants}

Non-enzymatic antioxidants interrupt free radical chain reactions. For example, vitamin $\mathrm{E}$ interrupts a chain of free radical activity after only five reactions. Other examples include vitamin C, plant polyphenols, carotenoids, Se, and GSH.

GSH (cysteine containing natural antioxidant) is called as the "master antioxidant" and is found in every single cell of your body, maximizing the activity of all the other antioxidants. GSH is a tripeptide with a gamma peptide linkage between the amine group of cysteine (which is attached by a normal peptide linkage to a glycine) and the carboxyl group of the glutamate side-chain [30].

GSH exists in both reduced (GSH) and oxidized (GSSG) states. In the reduced state, the thiol group of cysteine is able to donate a reducing equivalent $\left(\mathrm{H}^{++} \mathrm{e}^{-}\right)$to other unstable molecules such as ROS. In donating an electron, GSH itself becomes reactive but readily reacts with another reactive GSH to form GSH disulfide (GSSG). Such a reaction is probable due to the relatively high concentration of GSH in cells (up to $5 \mathrm{mM}$ in the liver).

GSH is regenerated from GSSG by the enzyme GSH reductase (GSR) [31] In healthy cells and tissue, more than $90 \%$ of the total GSH pool is in the reduced form (GSH) and $<10 \%$ exists in the disulfide form (GSSG). An increased GSSG-to-GSH ratio is considered indicative of oxidative stress.

\section{Enzymatic antioxidants}

Enzymatic antioxidants work by breaking down and removing free radicals. In general, these antioxidant enzymes flush out dangerous oxidative products by converting them into hydrogen peroxide, then 


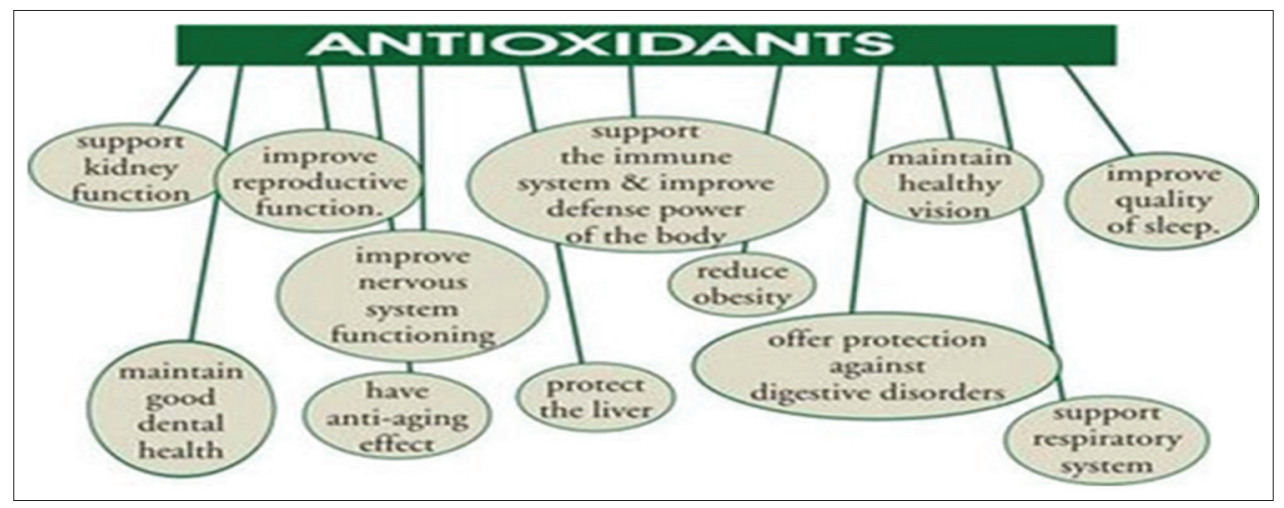

Fig. 3: Role of antioxidants

into water, in a multi-step process that requires a number of trace metal cofactors (copper, zinc, manganese, and iron). These enzymatic antioxidants cannot be supplemented orally but must be produced in our body.

The principle enzymatic antioxidants are the following.

\section{$S O D$}

Assisted by copper, zinc, manganese and iron, SOD breaks down superoxide (which plays a major role in lipid peroxidation) into oxygen and hydrogen peroxide. SOD is present in nearly all aerobic cells and extracellular fluids.

\section{CAT}

Converts hydrogen peroxide into water and oxygen (using iron and manganese cofactors), hence finishing up the detoxification process that SOD started.

\section{Selenoproteins}

These selenium-containing enzymes help break down hydrogen peroxide and organic peroxides into alcohols and are particularly abundant in liver. Selenium is an essential trace element having fundamental importance to human health as it is a constituent of the small group of selenocysteine-containing selenoproteins (over 25 different proteins) which are important for structural and enzymatic functions. Selenoproteins include several forms of the enzymes GSH peroxidase (GSHpx), thioredoxin reductase and iodothyronine deiodinase.

\section{GSHpx}

Catalyzes the elimination of hydrogen peroxide as well as organic peroxides (R-O-OH) by the oxidation of GSH [25].

\section{GSR}

Catalyzes the reduction of GSH disulfide (GSSG) to the sulfhydryl form GSH, which is a critical molecule in resisting oxidative stress and maintaining the reducing environment of the cell.

\section{WATER-SOLUBLE (HYDROPHILIC) AND LIPID-SOLUBLE (LIPOPHILIC) ANTIOXIDANTS}

Another categorization of antioxidants is based on whether they are soluble in water (hydrophilic) or in lipids (hydrophobic). The interior of our cells and the fluid between them are composed mainly of water but cell membranes are made largely made of lipids [32].

The lipid-soluble antioxidants (such as vitamins E and A, carotenoids, and lipoic acid) are primarily located in the cell membranes, whereas the water-soluble antioxidants (such as vitamin C, polyphenols, and GSH) are present in aqueous body fluids such as blood and the fluids within and around the cells (the cytosol, or cytoplasmic matrix). Free radicals can strike the watery cell contents or the fatty cellular membrane, so the cell needs defenses for both. The lipid-soluble antioxidants are the ones that protect the cell membranes from LPO.

\section{Natural and artificial antioxidants}

Antioxidants are divided into two groups according to their origin as "natural antioxidants" and "synthetic antioxidants." Most of the synthetic antioxidants are of the phenolic type. The differences in their antioxidant activities are related to their chemical structures, which also influence their physical properties such as volatility, solubility, and thermal stability.

Natural phenolic compounds are widely distributed in plants and are the main contributors to the antioxidant activities of food [33]. Many disorders, i.e., cancer, Parkinson's and Alzheimer's diseases, atherosclerosis or heart failure are connected with oxidative stress Therefore, the increasing interest in elucidating the antioxidant activity of different natural compounds $[34,35]$

The commercially available and currently used synthetic antioxidants are butylated hydroxyanisole (BHA), butylated hydroxytoluene (BHT), and tertbutyl hydroquinone (TBHQ) (Fig. 4).

In recent years, there is an increasing interest in natural antioxidants and subsequently looking through the literature; it is recognized that the replacement of synthetic antioxidants by natural ones may have several benefits and much of the research on natural antioxidants has focused on phenolic compounds, in particular, flavonoids as potential sources of natural antioxidants [36-38].

Numbers of naturally existing antioxidant compounds present in fruits, vegetables, and dietary supplements are ascorbic acid, $\alpha$-tocopherol, phenolic acids (benzoic acid, trans-cinnamic acid, and hydroxycinnamic acid), coumarins, lignans, stilbenes (in glycosylated form), flavonoids, isoflavonoids, and phenolic polymers (tannins) [39].

\section{Flavonoids as antioxidants}

Flavonoids are secondary plant products recognized as the characteristic red, blue and purple anthocyanin pigments of plant tissues. Apart from their physiological roles in the plants, flavonoids as important components in human diet but never considered as nutrient [40]. The basic structure of flavonoid is a phenylated benzopyrone consists of 3 rings $\mathrm{A}, \mathrm{B}$ and $\mathrm{C}$ (Fig. 5).

The various classes of flavonoids differ in the level of oxidation and pattern of substitution of the $\mathrm{C}$ ring. Among the various classes of flavonoids, the important ones are flavones, flavanones, isoflavones, flavonols, flavanol (catechin), flavanonols, flavan-3-ols, and anthocyanidins. Flavonoids are polyphenolic compounds representing the majority of plant secondary metabolites and have shown to possess remarkable health promoting effects including antioxidant activity [41] 


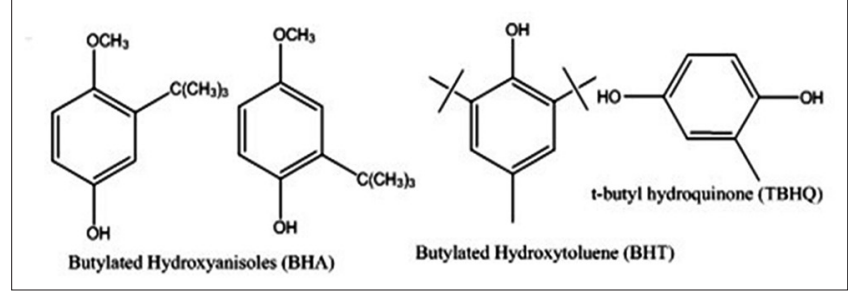

Fig. 4: Synthetic antioxidants

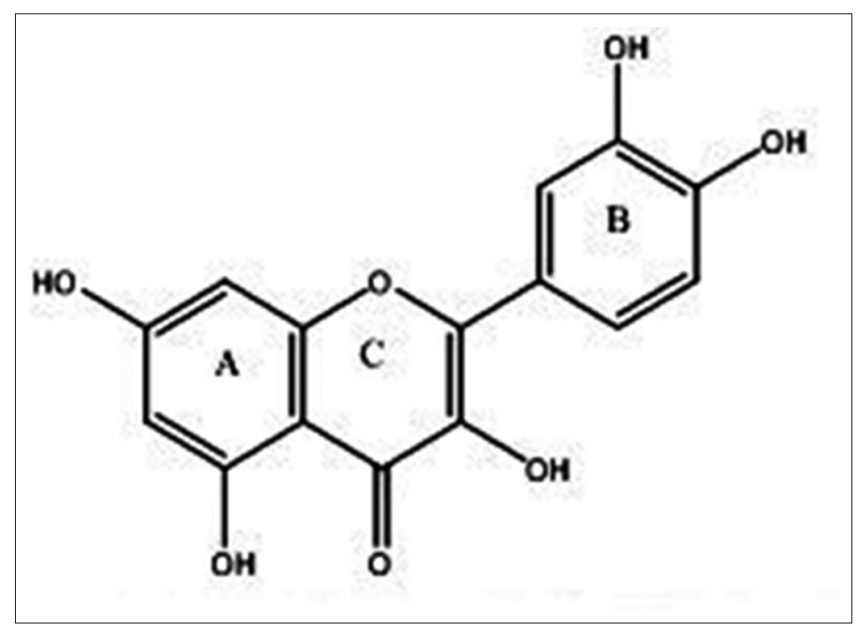

Fig. 5: Flavonoid

Aluminum chloride colorimetrilac estimation is commonly used to quantify flavonoid content of plant extracts [42]. Total flavonoid contents can be determined by reaction with sodium nitrite, followed by the development of colored flavonoid-aluminum complex formation using aluminum chloride in alkaline condition which can be monitored spectrophotometrically at a maximum wavelength of $510 \mathrm{~nm}$ [43].

\section{CLASSIFICATION OF ANTIOXIDANT METHODS [44]}

\section{In vitro antioxidant methods}

Antioxidant activity is not concluded based on a single antioxidant test model. There are several in vitro test procedures for evaluating antioxidant activities with the samples of interest. Another aspect is that antioxidant test models vary in different respects. Therefore, it is difficult to compare fully one method to another one. In general, in vitro antioxidant tests using free radical traps are relatively straightforward to perform. Among free radical scavenging methods, 1,1-diphenyl-2picrylhydrazyl (DPPH) method is furthermore rapid, simple (i.e. not involved with many steps and reagents) and inexpensive in comparison to other test models. On the other hand, 2, 2-azinobis (3-ethyl benzothiazoline-6-sulfonic acid) diamonium salt (ABTS) decolorization assay is applicable for both hydrophilic and lipophilic antioxidants. In this article, all in vitro methods are described and it is important to note that no one method is absolute in nature rather than an example. All in vitro antioxidant methods are listed in Table 1.

Based on the chemical reaction involved between the antioxidant compounds and the free radicals, antioxidant capacity assays are broadly classified into two types.

1. Hydrogen atom transfer (HAT) reaction based assays

2. Electron transfer (ET) reaction based assays.

\section{ET-based assays}

These assays measure the reducing capacity of the antioxidant compounds. It is based on the simple redox reaction, where antioxidant compounds reduce the free radicals and get themselves oxidized. Reduction by antioxidant compounds results in the color change of
Table 1: List of in vitro anti-oxidant methods

\begin{tabular}{ll}
\hline Serial number & Name of the antioxidant method \\
\hline 1. & In vitro antioxidant methods \\
1.1. & ET based assays \\
1.1 .1$. & DPPH free radical scavenging assay \\
1.1 .2$. & Superoxide anion radical scavenging assay \\
1.1 .3$. & FRAP \\
1.1 .4$. & TEAC, using ABTS \\
1.1 .5$. & CUPRAC assay \\
1.1 .6$. & FCR, the total phenols assay \\
1.1 .7$. & Reducing power assay \\
1.1 .8$. & DMPD assay \\
1.1 .9$. & Nitric oxide radical inhibition activity \\
1.1 .10$. & TBARS assay \\
1.2. & HAT based assays \\
1.2 .1$. & ORAC \\
1.2 .2$. & ABTS radical scavenging method \\
1.2 .3$. & Crocin Bleaching Assays \\
1.2 .4$. & TRAP \\
1.2 .5$. & Hydroxyl radical scavenging activity \\
1.2 .6$. & HORAC \\
1.2 .7$. & LPIC assay \\
1.2 .8$. & Scavenging of $\mathrm{H}_{2} \mathrm{O}_{2}$ radicals \\
1.2 .9$. & IOC \\
1.2 .10$. & PCL Assay \\
1.2 .11$. & $\beta-$ carotene-linoleic acid (linoleate) assay \\
1.3. & Other in vitro antioxidant methods \\
1.3 .1$. & Ascorbic acid content assay \\
1.3 .2$. & CAA \\
1.3 .3$. & EPR spectroscopy investigations \\
1.3 .4$. & Phosphomolybdenum assay \\
1.3 .5$. & Xanthine oxidase method \\
1.3 .6$. & Metal chelating activity \\
\hline & a
\end{tabular}

ET: Electron transfer, HAT: Hydrogen atom transfer, DPPH

1,1-diphenyl-2-picrylhydrazyl, FRAP: Ferric ion reducing antioxidant power TEAC: Trolox equivalence antioxidant capacity, ABTS: 2, 2-azinobis (3-ethyl benzothiazoline-6-sulfonic acid) diamonium salt, CUPRAC: Cupric ion reducing antioxidant capacity, FCR: Folin-Ciocalteu reagent, DMPD: N, N-dimethyl-p-Phenylenediamine, TBARS: Thiobarbituric acid reactive substances, ORAC: Oxygen radical absorbance capacity, TRAP: Total radical trapping antioxidant parameter, HORAC: Hydroxyl radical averting capacity, LPIC: Lipid peroxidation inhibition capacity, IOC: Inhibited oxygen uptake, PCL: Photochemiluminescence, CAA: Cellular antioxidant activity, EPR: Electron paramagnetic resonance

the reagent, which correlates with the antioxidant capacity, which is measured by the change in absorbance.

$\mathrm{X}^{*}+\mathrm{AH} \rightarrow \mathrm{X}^{-}+\mathrm{AH}^{\cdot+}$

$\mathrm{AH}^{\bullet+}+\mathrm{H}_{2} \mathrm{O} \rightarrow \mathrm{A} \bullet+\mathrm{H}_{3} \mathrm{O}^{+}$

$\mathrm{X}^{-}+\mathrm{H}_{3} \mathrm{O}^{+} \rightarrow \mathrm{XH}+\mathrm{H}_{2} \mathrm{O}$

\section{HAT-based assays}

These assays measures/quantify the hydrogen atom donating ability of the antioxidant compounds by a proton-coupled ET reaction, where it measures the chain breaking antioxidant capacity. These assays based on the reaction between synthetic free radical generator, oxidisable molecular probe, and an oxidant where reaction kinetics is derived from the kinetic curve.

\section{$\mathrm{X}^{\bullet}+\mathrm{AH} \rightarrow \mathrm{X}^{-}+\mathrm{AH}^{\cdot+}$}

\section{ET-based assays}

1. DPPH free radical scavenging assay

2. Superoxide anion radical scavenging assay

3. Ferric ion reducing antioxidant power (FRAP)

4. Trolox equivalence antioxidant capacity (TEAC), using ABTS

5. Cupric ion reducing antioxidant capacity (CUPRAC) assay 
6. Folin-Ciocalteu reagent (FCR), the total phenols assay

7. Reducing power assay

8. N,N-dimethyl-p-phenylenediamine (DMPD) assay

9. NO radical inhibition activity

10. Thiobarbituric acid reactive substances (TBARS) assay.

\section{HAT-based assays}

1. Oxygen radical absorbance capacity (ORAC),

2. ABTS radical scavenging method

3. Crocin bleaching assays (CBA),

4. Total radical-trapping antioxidant parameter (TRAP),

5. Hydroxyl radical scavenging activity

6. Hydroxyl radical averting capacity (HORAC)

7. LPO inhibition capacity (LPIC) assay

8. Scavenging of $\mathrm{H}_{2} \mathrm{O}_{2}$ radicals

9. Inhibited oxygen uptake (IOC)

10. Photochemiluminescence (PCL) assay

11. $\beta$-carotene-linoleic acid (linoleate) assay.

Antioxidant testing of natural products has increasing interest in recent years, mainly due to the fact that antioxidants can neutralize the harmful free radicals in vitro, thus suggesting that an antioxidant-rich diet, provides health benefits.

\section{ET-based assays}

DPPH radical scavenging activity (Fig. 6)

The DPPH is one of the most stable free radicals and is frequently used in the evaluation of radical scavengers in natural foods [45]. DPPH assay method is very simple and is also quick for manual analysis of antioxidant contents. This method can be used for solid or liquid samples and is not only specific to any particular antioxidant but also applies to the overall antioxidant capacity of the sample.

The DPPH test is based on the ability of the stable 2, 2-diphenyl-1picrylhydrazyl free radical to react with hydrogen donors [46,47].

DPPH assay method is based on the reduction of DPPH, a stable free radical. The free radical DPPH with an odd electron gives a maximum absorption at $517 \mathrm{~nm}$ (purple). When antioxidants react with DPPH, the stable free radical becomes paired off in the presence of a hydrogen donor (e.g., a free radical-scavenging antioxidant) and is reduced to the DPPHH and as consequence the absorbances decreased from the DPPH Radical to the DPPH-H form, results in decolorization (yellow) with respect to the number of electrons captured. More the decolorization, more is the reducing ability. This test has been the most accepted model for evaluating the free radical scavenging activity of any new drug. The DPPH radical displays an intense UV-visible (UV-Vis) absorption spectrum. When a solution of DPPH is mixed with that of a substance that can donate a hydrogen atom, then this gives rise to the reduced form (diphenyl picryl hydrazine; nonradical) with the loss of violet (pale yellow of the picryl group present) [48].

In this test, a solution of radical is decolorized after reduction with an antioxidant $(\mathrm{AH})$ or a radical (R) according to the following equation [49]:

$(\mathrm{DPPH})+\mathrm{H}-\mathrm{A} \rightarrow \mathrm{DPPH}-\mathrm{H}+\mathrm{A}$ or DPPH $+\mathrm{R} \rightarrow \mathrm{DPPH}-\mathrm{R}$

(Purple) (Yellow)

About $4.3 \mathrm{mg}$ of DPPH was dissolved in $3.3 \mathrm{ml}$ methanol and protected from light by covering the test tubes with aluminum foil. $150 \mathrm{ml}$ DPPH solution was added to $3 \mathrm{ml}$ methanol, and the absorbance was taken immediately at $517 \mathrm{~nm}$ for control reading. $50 \mathrm{ml}$ of various concentrations of compounds as well as standard compound (e.g., ascorbic acid) were taken, and the volume was made uniformly to $150 \mathrm{ml}$ using methanol. Each of the samples was then further diluted with methanol up to $3 \mathrm{ml}$ and to each $150 \mathrm{ml}$ DPPH was added. The

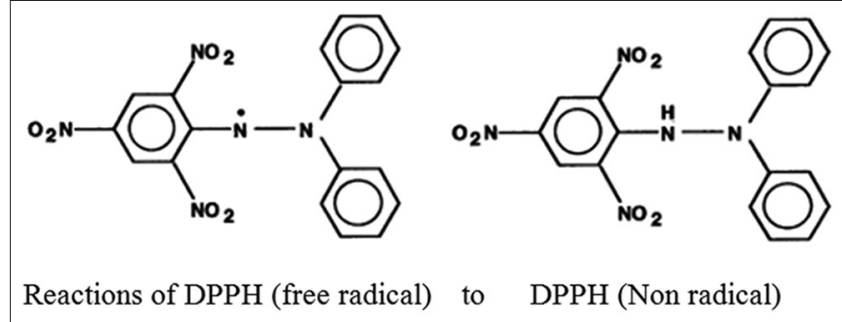

Fig. 6: 1, 1-diphenyl-2-picrylhydrazyl

absorbance was taken after 15 minutes at $517 \mathrm{~nm}$ using methanol as blank on UV-vis spectrometer Shimadzu, UV-1601. The IC ${ }_{50}$ values for each drug compounds as well as standard preparation were calculated. The free radical scavenging activity was calculated using the following formula:

$\%$ scavenging=[Absorbance of control-Absorbance of test sample/ Absorbance of control $] \times 100$

The effective concentration of sample required to scavenge DPPH radical by $50 \%\left(\mathrm{IC}_{50}\right.$ value) was obtained by linear regression analysis of dose-response curve plotting between $\%$ inhibition and concentrations.

The better way of comparison of antioxidant activity between the samples is using $\mathrm{IC}_{50}$ values. Inhibition concentration $\left(\mathrm{IC}_{50}\right)$ values defined as the concentration of sample required for $50 \%$ inhibition of free radicals. $\mathrm{IC}_{50}$ is determined from the plot between the remaining absorbance of free radical and concentration with each analysis in triplicates. In this test, quercetin, 6-hydroxy-2,5,7,8-tetramethyl chroman-2-carboxylic acid (trolox), tocopherol, and ascorbic acid are used as positive controls [50,51].

The DPPH analysis is a fast and an uncomplicated test ensuring reliable result. Furthermore, it requires only a UV-Vis spectrophotometer to perform, which explains its widespread use in screening antioxidant properties. However, the method is sometimes complicated when test compounds have spectra that overlap with DPPH at $515 \mathrm{~nm}$.

\section{Modifications}

DPPH is stable nitrogen radical that bears no similarity to the highly reactive and transient peroxyl radicals involved in LPO.

a. Conventional cuvette assay of radical scavenging activity is replaced by 96 -well plate titer assay from past couple of years. Cuvette assay method uses UV-Vis spectrophotometer to see the absorbance, whereas 96-well plate method uses ELISA plate reader for absorbance. The first method is very tedious, time-consuming method, allows only 1 sample to read a time and requires a high quantity of reagent, whereas the second method is time saving and it reads about 96 samples at a time, with a small amount of reagent.

b. Thin layer chromatography (TLC) autography technique

The antiradical screening by TLC autography technique provides an easy, effective and rapid way to study plant extract profiles. No sample purification is needed as this technique provided a simultaneous separation and radical scavenging activity measurement of antioxidative compounds in plant extract. Qualitative as well as semi-quantitative analysis of antioxidants can be done by this technique.

\section{Qualitative analysis}

To detect the antioxidant activity, a method based on the reduction of 2,2-diphenyl-1- Picrylhydrazyl (DPPH) can be carried out. DPPH is a free radical stable at room temperature, which produces a violet solution in methanol. When the free radical reacts to an antioxidant, its free radical property is lost due to chain breakage and its color changes to light yellow. In this assay by TLC, the extracts that produced yellow or white spots in the purple background were considered as antioxidants. 
Procedure

The extracts dissolved in the solvent were spotted on the silica-gel 60F 254 plates and developed the chromatogram in adequate solvent systems. Then, all the plates are sprayed with a methanolic solution of DPPH $(2 \mathrm{mg} / \mathrm{ml})$. Thus, antioxidants appear as yellow bands on a light purple background. After spotting the extracts on the TLC plates, even uneluted plates also can be used to determine the qualitative antioxidant analysis. The uneluted plates also can immerse in $0.2 \%$ DPPH methanol solution and sample spots were evaluated for radical scavenging activity.

The same method is also implemented to detect total phenolic and total flavonoid content just by changing the mobile phase solvent system and visualizing agent. Vanillin $/ \mathrm{H}_{2} \mathrm{SO}_{4}$ reagent is sprayed on the plate and heating it at $110^{\circ} \mathrm{C}$, for 5 minutes and observed to detect different groups of compounds. Orange-yellow spots indicate polyphenolic compounds. The silicagel plate was sprayed with natural products-PEG reagent and observed at UV-365 $\mathrm{nm}$, to detect the flavonoids as they appear as yellow-orange fluorescent spots.

A disadvantage of DPPH method is the fact that many antioxidants that react quickly with the radical peroxide are almost or entirely inert to DPPH. Despite having the above limitations, DPPH is stable, is commercially-available and does not have to be generated before carrying out assays like ABTS. For these reasons, it is considered as an easy and useful spectrophotometric method with regard to screening or measuring the antioxidant activity.

\section{Super oxide free radical scavenging activity}

Superoxide anion $\left(\mathrm{O}_{2}^{--}\right)$is an oxygen molecule with an extra electron that can damage mitochondria, DNA, and other molecules. Superoxide generated both in vivo and in foods can undergo several reactions including dismutation to give $\mathrm{H}_{2} \mathrm{O}_{2}$

$\mathrm{O}_{2} \cdot{ }^{--}+\mathrm{O}_{2} \cdot{ }^{--}+2 \mathrm{H}^{+} \rightarrow \mathrm{H}_{2} \mathrm{O}_{2}+\mathrm{O}_{2}$

Superoxide is biologically important as it can form singlet oxygen and hydroxyl radical. Overproduction of superoxide anion radical contributes to redox imbalance and associated with harmful physiological consequences.

Superoxide anions are generated in phenazine methosulfatenicotinamide adenine dinucleotide (NADH) system by the oxidation of NADH and assayed by the reduction of nitro-blue tetrazolium (NBT) resulting in the formation of blue formazan.

\section{Procedure}

A value of $100 \mathrm{ml}$ of riboflavin solution $(20 \mathrm{mg}), 200 \mathrm{ml}$ ethylenediaminetetraacetic acid (EDTA) solution (12 mM), $200 \mathrm{ml}$ methanol, and $100 \mathrm{ml} \mathrm{NBT}$ solution $(0.1 \mathrm{mg})$ were mixed in test tube and reaction mixture was diluted up to $3 \mathrm{ml}$ with phosphate buffer $(50 \mathrm{mM})$. The absorbance of the solution was measured at $590 \mathrm{~nm}$ using phosphate buffer as blank after illumination for 5 minutes. This is taken as control. $50 \mathrm{ml}$ of different concentrations of compounds as well as standard preparation were taken and diluted up to $100 \mathrm{ml}$ with methanol. To each of these, $100 \mathrm{ml}$ Riboflavin, $200 \mathrm{ml}$ EDTA, $200 \mathrm{ml}$ methanol, and $100 \mathrm{ml}$ NBT were mixed in test tubes and further diluted up to $3 \mathrm{ml}$ with phosphate buffer. The absorbance was measured after illumination for 5 minutes at $590 \mathrm{~nm}$ on UV-Vis spectrometer. The $\mathrm{IC}_{50}$ values for each compound as well as for the standard preparation were calculated using the following formula [52-60].

$\%$ Inhibition=[Absorbance of control-Absorbance of test sample/ Absorbance of control] $\times 100$

\section{FRAP assay}

FRAP is another method employed for the determination of total antioxidant activities. Primarily used for determining antioxidant activity of plasma, later successfully applied to measure the antioxidant activity of a number of biological samples and pure substances [61-63]. Since antioxidant and antiradical properties are mainly attributed to the presence of phenolic compounds [64,65], it is expected that the effectiveness of a fraction is proportional to its phenolic concentrations. FRAP assay is widely-used to directly test the total antioxidant potential of several foods and plant extracts based on the reduction of complexes of 2,4,6-tripyridyl-s-triazine (TPTZ) with ferric chloride hexahydrate $\left(\mathrm{FeCl}_{3} \cdot 6 \mathrm{H}_{2} \mathrm{O}\right)$, which are almost colorless. The solution will eventually turn slightly brownish forming blue ferrous complexes after complete reduction.

FRAP assay uses antioxidants as reductants in a redox-linked colorimetric method, employing an easily reduced oxidant system present in stoichiometric excess. The test solutions are mixed with a FRAP reagent $\left(10 \mathrm{mM}\right.$ of TPTZ solution in $40 \mathrm{mM} \mathrm{HCl}, 20 \mathrm{mM} \mathrm{FeCl}_{3}$, and $0.3 \mathrm{M}$ acetate buffer at $\mathrm{pH} 3.6$ ) followed by spectrophotometric measurement of the absorbance of the reaction mixture after incubation at $37^{\circ} \mathrm{C}$ for 10 minutes at $593 \mathrm{~nm}$ against the blank. The final results can be expressed as the concentration of antioxidants having a ferric reducing ability equivalent to that of $1 \mathrm{mM} \mathrm{FeSO}_{4}$ used as the standard solution.

FRAP method has limitations, especially for measurements below nonphysiological $\mathrm{pH}$ values, i.e., at $\mathrm{pH}$ 3.6. In addition, this method is unable to detect slowly-reacting polyphenolic compounds and thiols [66]. Furthermore, any compounds (even without antioxidant properties) with redox potential lower than that of the redox pair $\mathrm{Fe}^{(3+)} / \mathrm{Fe}^{(2+)}$ can theoretically reduce $\mathrm{Fe}^{(3+)}$ to $\mathrm{Fe}^{(2+)}$ contributing to an increase in the FRAP value and thus inducing false positive results [67]. On the other hand, not all antioxidants reduce $\mathrm{Fe}^{(3+)}$ at a rate fast enough to allow its measurement within the observation time (typically 4 minutes). Indeed, many polyphenols react more slowly and require longer reaction times (30 minutes) for total quantification. Moreover, some polyphenolic compounds such as quercetin, caffeic, ferulic, and tannic acids have slower reactions, requiring a longer time (approximately $30 \mathrm{~min}$ ) until the complex reduction process was completed. When used to determine the antioxidant potential of polyphenols in water and methanol, the change in absorbance continued after 4 minutes [68]. Therefore, the FRAP values for these compounds cannot be accurately determined in 4 minutes. Hence for this reason, the ideal reaction time should be at least 10 minutes.

Procedure

An aliquot of $0.20 \mathrm{ml}$ of each sample at appropriate concentration was mixed with $0.5 \mathrm{ml}$ of phosphate buffered saline $(0.2 \mathrm{M}$; pH 6.6) and $0.5 \mathrm{ml}$ of $1 \%$ potassium ferricyanide $\left(\mathrm{K}_{3} \mathrm{Fe}(\mathrm{CN})_{6}\right)$. The mixture was incubated at $50^{\circ} \mathrm{C}$ for 30 minutes and $0.5 \mathrm{ml}$ of $10 \%$ trichloroacetic acid (TCA) was added. After centrifugation for 10 minutes at $3000 \mathrm{rpm}$, the supernatant $(0.5 \mathrm{ml})$ was mixed with distilled water $(0.5 \mathrm{ml})$ and $0.1 \%$ ferric chloride $(0.1 \mathrm{ml})$. The absorbance was measured at $700 \mathrm{~nm}$; ascorbic acid was used as positive control. Absorbance increasing relatively to that of concentration represented the reducing capacity of tested sample.

\section{Statistical analyses}

Data were expressed as a mean \pm standard deviation. Analyses of variance (ANOVA) were performed for the comparison of results using Fischer's test. A statistical significance was set at $\mathrm{p}<0.05$.

\section{TEAC assay}

TEAC measures the antioxidant activity of a given substance, as compared to the standard, trolox [69]. The three TEAC tests developed at different periods - namely, TEAC assay I (ABTS) enzymatically-generated with met-myoglobin and hydrogen peroxide, TEAC II radical generation with filtration over the manganese dioxide $\left(\mathrm{MnO}_{2}\right)$ oxidant, and TEAC III (with potassium persulfate $\left[\mathrm{K}_{2} \mathrm{~S}_{2} \mathrm{O}_{8}\right]$ oxidant) even though were totally different from 
one another - are interchangeably-used, when using different solvent media. This leads to significant variability in the measurements of the antioxidants $[70,71]$.

The "pre-addition technique" (employed by adding antioxidants before radical generation) for TEAC I could result in an overestimation of antioxidant capacity because many substances interfere with the formation of the free radical; TEAC I measured the ability of delaying radical formation as well as scavenging of the radical [71]. Since the reagent is soluble in both aqueous and organic solvent media, the advantages of ABTS/TEAC are reported to be operational simplicity, reproducibility, diversity and the most important of all, flexible usage in multiple media to determine both hydrophilic and lipophilic antioxidant capacity of food extracts and physiological fluids [72]

\section{CUPRAC Assay}

CUPRAC is an ET-based assay which is widely and popularly used method to determine the complete scavenging of free radicals, i.e. total antioxidant capacity of a compound. This method is based on the simple redox reaction between antioxidant and the free radicals, where the antioxidant activity can be measured by reduction of cupric ions to cuprous ions by antioxidants $[73,74]$.

The novel in vitro antioxidant method based on an electron-transfer mechanism was named as CUPric ion reducing antioxidant capacity, abbreviated as the CUPRAC method. These CUPRAC method is widely used to measure the antioxidant capacity assays in food, plants, human serum, biological samples, dietary polyphenols, vitamins $\mathrm{C}$ and $\mathrm{E}$, etc. This assay is a simple, reliable, versatile and has low cost. Antioxidant capacity was compared and found advantageous over other methods CUPRAC assays are popular, due to their high speed and sensitivity and also extensively validated and provides useful information about the reducing capacity of the sample.

\section{Chemistry behind CUPRAC assay}

Neocuproine is an aromatic heterocyclic compounds used for the spectroscopic determination of copper. Neocuproine, a methylated phenanthroline derivative chelates with the copper from cuprous chloride and forms a chromogenic redox reagent bis(neocuproine) copper II) chloride, which is a novel reagent for the CUPRAC antioxidant capacity assays. This assay is based on reduction of $\mathrm{Cu}$ (II)-neocuproine complex to highly colored $\mathrm{Cu}(\mathrm{I})$-neocuproine complex, which is measured at $450 \mathrm{~nm}$ absorbance.

The generation of cuprous ions $\left(\mathrm{Cu}^{1+}\right)$ from cupric ions $\left(\mathrm{Cu}^{2+}\right)$ is due to reduction of cupric chloride from cuprous chloride in the chromogenic redox reagent bis(neocuproine) copper(II) chloride by antioxidants compounds. This copper(I) is highly selective toward neocuproine, the resulting $\mathrm{Cu}(\mathrm{I})$-neocuproine complex consists of two molecules of neocuproine with one cuprous ion, with a maximum absorption at $454 \mathrm{~nm}$ [75] (Fig. 7).

\section{CUPRAC methodology}

This method involves mixing the antioxidant solution with aqueous copper(II) chloride, alcoholic neocuproine, and ammonium acetate aqueous buffer at $\mathrm{pH} 7$, and subsequently measuring the developed absorbance at $450 \mathrm{~nm}$ after 30 minutes.

Preparation of Solutions

1. $\mathrm{CuCl}_{2}$ solution $1.0 \times 10^{-2} \mathrm{M}(10 \mathrm{mM}$ is prepared by dissolving $0.4262 \mathrm{~g}$ $\mathrm{CuCl}_{2} .2 \mathrm{H}_{2} \mathrm{O}$ in water, and diluting to $250 \mathrm{~mL}$

2. Ammonium acetate buffer at $\mathrm{pH}=7.0,1.0 \mathrm{M}$ is prepared by dissolving $19.27 \mathrm{~g} \mathrm{NH}_{4} \mathrm{Ac}$ in water and diluting to $250 \mathrm{~mL}$

3. Neocuproine (Nc) solution, $7.5 \times 10^{-3} \mathrm{M}(7.5 \mathrm{mM})$ is prepared by dissolving $0.039 \mathrm{~g} \mathrm{Nc}$ in $96 \%$ ethanol, and diluting to $25 \mathrm{~mL}$ with ethanol. This solution should be prepared freshly

4. Trolox, $1.0 \times 10^{-3} \mathrm{M},(1 \mathrm{mM})$ is prepared by dissolving $0.00626 \mathrm{~g}$ of the compound in $96 \%$ ethanol, and diluting to $50 \mathrm{~mL}$.

The standard CUPRAC procedure involves the addition of cuprous chloride along with neocuproine reagent, bathocuproine, a chromogenic Reducing agent, which reacts with the antioxidant molecules, and converts cupric to cuprous, to form a $\mathrm{Cu}(\mathrm{I})-\mathrm{Nc}$ complex.

The method is summarized

Add $1 \mathrm{~mL}$ of $10 \mathrm{mM} \mathrm{CuCl}_{2}$ solution, $1 \mathrm{~mL} 7.5 \mathrm{mM}$ neocuproine, $1 \mathrm{~mL} 1 \mathrm{M}$ $\mathrm{NH}_{4} \mathrm{Ac}$, and $\mathrm{x} \mathrm{mL}$ of antioxidant neutral solution then makeup the final volume to $4.1 \mathrm{~mL}$ using distilled water. Incubate the reaction mixture under normal condition (room temperature) for 30 minutes, after incubation the absorbance was read at $450 \mathrm{~nm}$.

\section{Expressing units for CUPRAC assay}

The antioxidant activity evaluated by different antioxidant methods can be expressed as millimole/micromole equivalent of reference standard used. The antioxidant compounds used as reference standard includes vitamin E, ascorbic acid, gallic acid, BHA, BHT, trolox, etc. TE (trolox equivalent [TE]) is a parameter widely used to measure the antioxidant activity where trolox is used as the standard reference to measure antioxidant capacity of the samples.

$\mathrm{EC}_{50}$ and $\mathrm{IC}_{50}$ are also used to evaluate the antioxidant activity of the sample, which were determined using the liner regression graph of concentration against the mean radical scavenging percentage of the antioxidant sample.

Advantages of CUPRAC method

The novel reagent for the CUPRAC antioxidant capacity assay is bis(neocuproine) copper(II) chloride. This CUPRAC reagent was easily accessible, stable, selective low-cost, and responding to all antioxidants which induce redox reaction with the antioxidant compounds and determines the antioxidant capacity of various compounds.

CUPRAC method is advantageous over other electron-transfer based methods as follows:

1. The CUPRAC assay proved to be efficient for GSH and thiol-type antioxidants due to electronic structure of $\mathrm{Cu}(\mathrm{II})$ facilitate faster kinetics, whereas FRAP method which is carried out at low $\mathrm{pH}$ found to be insensitive to thiol group of antioxidants due to chemical inertness by the half filled d-orbitals of high spin Fe(III).

2. CUPRAC is superior with respect to $\mathrm{pH}$ which is close to the physiological pH condition ( $\mathrm{pH} 7$ ) unlike FRAP which is carried out

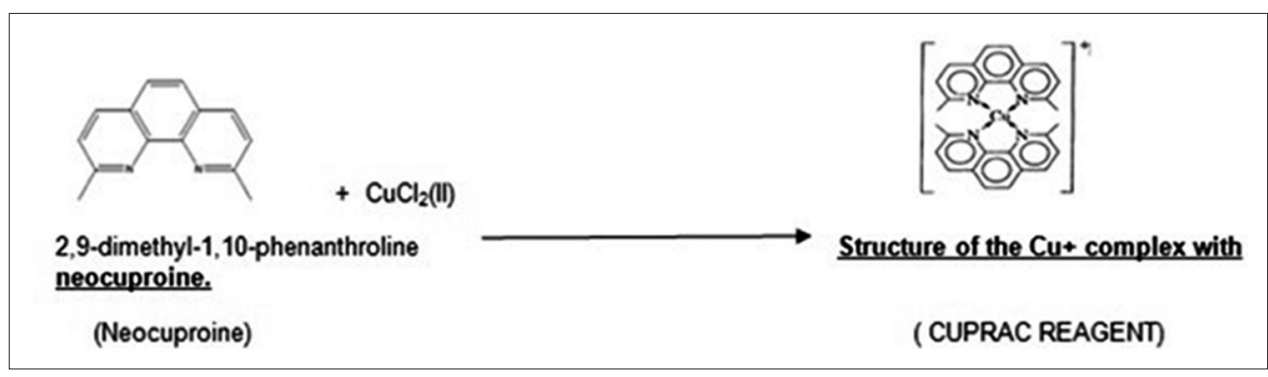

Fig. 7: Cupric ion reducing antioxidant capacity reaction 
at acidic condition, folins methods which are carried out at alkaline conditions. The reaction at acidic and alkaline conditions will suppress or enhances the reduction capability of the sample thereby altering the reducing capability of the antioxidant compounds. Thus, CUPRAC gives definite values under physiological conditions.

3. CUPRAC method found to be superior method to analyze biological fluids over widely used Folin-Ciocalteu, whereas this method is applicable to both lipophilic serum antioxidants as well as hydrophilic serum antioxidants. Hence, this method is useful in determining the total antioxidant capacity of the biological fluids.

4. Colored reagent used in the antioxidant assay is usually sensitive toward light, humidity, $\mathrm{pH}$, solvents like DPPH reagent, whereas cuprac reagent-colored chelate of $\mathrm{Cu}(\mathrm{I})-\mathrm{Nc}$ found to be stable and insensitive to the all external parameters.

5. Proxidants are species that causes oxidation of biological macromolecule, and results in oxidative stress. In the ferric ion based assays such as FRAP produces $\mathrm{Fe}^{2+}$, which can act as prooxidant by producing $\mathrm{OH}$ radicals by reacting with $\mathrm{H}_{2} \mathrm{O}_{2}$.

Application of CUPRAC method in food, biological fluids, and plant extracts

Beneficial influence of many foodstuffs, fruits, vegetables, and beverages including, tea, coffee is attributed due to their plant-derived antioxidants. To determine the complete profiling of antioxidant capacity in foodstuffs, beverages nutraceutical, dietary supplements, etc., there is a need to develop standardized antioxidant capacity methods. Cuprac assay is the most commonly used in vitro determination of antioxidant activity of food constituents.

CUPRAC method is widely applicable for measuring the antioxidant capacity in various food compounds namely vitamins (vitamins C and E), dietary polyphenols, flavonoids, ascorbic acid in food extract. Measuring the antioxidant capacity of plant-derived antioxidant by cuprac method in the wide range of matrices such as food, beverages, biological fluids, and plant extracts give the more appropriate biological activity information as it measures total antioxidant capacity of the matrices.

Antioxidant activity of biological fluids like serum, plasma antioxidants can be carried out using CUPRAC assay. These tests measures the combined effect of nonenzymatic antioxidants present in the biological fluids, hence it is of the most important by providing the complete picture on the antioxidant status of the organism and their ability to counter act with free radicals/ROS. There is no single widely acceptable specific method for biological samples but cuprac method found to be useful in determining the biologically important molecules such as Ascorbic acid, $\alpha$-tocopherol, reduced GSH, uric acid, bilirubin, and albumin-carotene $[76,77]$.

Cuprac method results when correlated with other spectrophotometric assays such as FRAP, TEAC, and DPPH are found to be advantages compared to other methodologies for antioxidant capacity assessment of plasma and urine samples. CUPRAC method is prominent to measure the total antioxidant capacity of biological fluids along with other commonly used methods.

Polyphenols are a group of chemicals found in many fruits, vegetables, and other plants such as tea leaves and grapes. They possess antioxidant properties due to their phenolic $-\mathrm{OH}$ group. Polyphenol profiling is done using CUPRAC methods were various polyphenol groups which differ on number and position of $-\mathrm{OH}$ groups can be reduced/oxidized by CUPRAC reagent. Polyphenols, flavonoid containing plant extracts can be measured easily and antioxidant profiling of different plant extracts can be done [78-80].

\section{FCR, the total phenols assay}

FCR is a mixture of tungsten and molybdenum oxides. This method was previously used for the analysis of proteins like tyrosine [81] containing a phenolic group but later applied for analyzing the total phenolic content in wine. It is a sensitive, quantitative, and relatively independent method for proteins, nucleic acids, and ascorbic acid.

The product of metal oxide reduction produces a blue with a broad light absorption at $765 \mathrm{~nm}(750-770 \mathrm{~nm})$. Most of the phenolic compounds are in dissociated form (as conjugate bases or phenolate anions) at the working $\mathrm{pH} \sim 10$, they can be easily oxidized with the FCR.

The molybdenum center in the complex reagent is reduced from Mo (VI) to Mo (V) with an e-donated by an antioxidant to produce a blue. The intensity of light absorption at that wavelength is proportional to the concentration of phenols and results are expressed in gallic acid equivalents (GAE). Phenols stoichiometrically reduce phosphomolybdic/phosphotungstic acid [82]. The FC chromophore which is a multivalent charged phospho-tungsto-molybdate (V) having a great affinity for water was found to be incapable of measuring lipophilic antioxidants, but the reagent was modified and standardized to enable simultaneous measurements of lipophilic and hydrophilic antioxidants in $\mathrm{NaOH}$ added isobutanol-water medium by Apak et al. [83].

\section{Modification}

The modified procedure was successfully applied to the total antioxidant capacity assay of trolox, quercetin, ascorbic acid, gallic acid, catechin, caffeic acid, ferulic acid, rosmarinic acid, GSH, and cysteine aswell as of lipophilic antioxidants such as $\alpha$-tocopherol (Vitamin E), BHA, BHT, TBHQ, lauryl gallate, and $\beta$-carotene.

Heteropolyphosphotungstate - molybdate $=\frac{\text { Phenol }}{\text { Reduced forms }} \rightarrow$

(Tungstate series P2W180 ${ }_{62}^{-7} \rightarrow \mathrm{H} 4 \mathrm{P} 2 \mathrm{~W} 18062^{-8}$ )

(Molybdate series H2P2Mo18062 ${ }^{-6} \rightarrow \mathrm{H}^{2} 2 \mathrm{Mo} 180_{62}{ }^{-6}$ )

\section{Reducing power assay}

Potassium ferricyanide reducing power assay

This method is based on the reduction of ferric $\left(\mathrm{Fe}^{3+}\right)$ to ferrous $\left(\mathrm{Fe}^{2+}\right)$, in the presence of antioxidants. Substances having a reduction potential react with potassium ferricyanide forming potassium ferrocyanide which further reacts with $\mathrm{FeCl}_{3}$ to form an intense prussian blue complex having maximum absorbance at $700 \mathrm{~nm}$. The amount of complex formed is directly proportional to the reducing power of test sample [84].

The reducing power was determined according to the method of Oyaizu [85]. Various concentrations of extracts $(2.5 \mathrm{ml})$ were mixed with $2.5 \mathrm{ml}$ of $200 \mathrm{mmol} / \mathrm{l}$ sodium phosphate buffer (pH 6.6) and $2.5 \mathrm{ml}$ of $1 \%$ potassium ferricyanide. The mixture was incubated at $50^{\circ} \mathrm{C}$ for 20 minutes. After $2.5 \mathrm{ml}$ of $10 \%$ TCA (w/v) were added, the mixture was centrifuged at $650 \mathrm{rpm}$ for 10 minutes. The upper layer $(5 \mathrm{ml})$ was mixed with $5 \mathrm{ml}$ deionized water and $1 \mathrm{ml}$ of $0.1 \%$ of ferric chloride, and the absorbance was measured at $700 \mathrm{~nm}$ : Higher absorbance indicates higher reducing power. The assays were carried out in triplicate and the results are expressed as mean values \pm standard deviations. The extract concentration providing 0.5 of absorbance $\left(\mathrm{EC}_{50}\right)$ was calculated from the graph of absorbance at $700 \mathrm{~nm}$ against extract concentration. BHA and tocopherol were used as standards. In this assay, the yellow of the test solution changes to various shades of green and blue, depending on the reducing power of each compound. The presence of reducers (i.e., antioxidants) causes the reduction of the $\mathrm{Fe}^{3+} /$ ferricyanide complex to the ferrous form. Therefore, measuring the formation of Perl's Prussian blue at $700 \mathrm{~nm}$ can monitor the $\mathrm{Fe}^{2+}$ concentration.

Procedure

The extract $(0.75 \mathrm{ml})$ at various concentrations was mixed with $0.75 \mathrm{ml}$ of phosphate buffer ( $0.2 \mathrm{M}, \mathrm{pH} 6.6)$ and $0.75 \mathrm{ml}$ of potassium 
hexacyanoferrate $\left(\mathrm{K}_{3} \mathrm{Fe}(\mathrm{CN})_{6}\right)(1 \%, \mathrm{w} / \mathrm{v})$, followed by incubating at $50^{\circ} \mathrm{C}$ in a water bath for 20 minutes. The reaction was stopped by adding $0.75 \mathrm{ml}$ of TCA solution (10\%) and then centrifuged at $800 \mathrm{~g}$ for 10 minutes. $1.5 \mathrm{ml}$ of the supernatant was mixed with $1.5 \mathrm{ml}$ of distilled water and $0.1 \mathrm{ml}$ of ferric chloride solution $(0.1 \%, \mathrm{w} / \mathrm{v})$ for 10 minutes. The absorbance was measured at $700 \mathrm{~nm}$ as the reducing power. Higher the absorbance of the reaction mixture, greater the reducing power.

\section{DMPD assay}

DMPD is an improved decolorization method developed by Verde [86] for measuring the antioxidant activity of samples.

The purple colored DMPD radical cation (DMPD ${ }^{+}$) generated through a reaction between DMPD and potassium persulfate is reduced in the presence of $\mathrm{H}$ donating antioxidants [87]. The determination of antioxidant potential is done at $\mathrm{pH} 5.25$ using $0.1 \mathrm{M}$ acetate buffer. One $\mu \mathrm{L}$ of DMPD* (stable up to $12 \mathrm{hrs}$ ) solution and $50 \mu \mathrm{L}$ antioxidant solution were mixed continuously for 10 minutes at $25^{\circ} \mathrm{C}$, then the absorbance of the solution was taken at $517.4 \mathrm{~nm}$.

The advantage of this method, compared to earlier methods, is Fe(II) ions involved in generation of radical cation through Fenton's reaction causes negative deviation in the antioxidant activity of food extracts. This assay is equally applied to both lipophilic and hydrophilic antioxidants. This method is rapid and inexpensive and reproducible, therefore used in screening a large number of fruit samples [88].

\section{NO free radical scavenging activity}

NO is involved in a variety of biological functions including neurotransmission, vascular homeostasis, antimicrobial, and antitumor activities. It also leads to oxidative damage. NO reacts with superoxide and forms the peroxynitrite anion, which is a potential oxidant that decompose and produces $\mathrm{OH}$ and $\mathrm{NO}$.

\section{Procedure}

Sodium nitroprusside in aqueous solution at physiological $\mathrm{pH}$ generates NO which interacts with oxygen to produce nitrite ions, estimated using Griess reagent. Scavengers of NO compete with oxygen, leading to reduced production of nitrite ions. Large amounts of NO leads to tissue damage.

About $50 \mathrm{ml}$ of each of the concentrations of compounds dissolved in DMSO and ascorbic acid (standard compound) were taken in separate tubes, and the volume was uniformly made up to $150 \mathrm{ml}$ with methanol. To each tube, $2.0 \mathrm{ml}$ of sodium nitroprusside $(10 \mathrm{mM})$ in phosphate buffer saline was added. The solutions were incubated at room temperature for 150 minutes. The similar procedure was repeated with methanol as blank which served as control. After incubation $5 \mathrm{ml}$ of Griess reagent was added to each tube including control. The absorbance of chromophore formed was measured at $546 \mathrm{~nm}$ on UV-Vis spectrometer Shimadzu, UV-1601. Ascorbic acid was used as a positive control. The $\mathrm{IC}_{50}$ values for each test compound as well as standard preparation were calculated [89-93].

$\%$ scavenging=[Absorbance of control-Absorbance of test sample/ Absorbance of control] $\times 100$

\section{TBARS assay}

The measurement of TBARS is a well-established method for screening and monitoring LPO [94]. The assay measures the inhibition of production of TBARS from sodium benzoate under the influence of the free oxygen radicals derived from Fenton's reaction. A solution of $1 \mathrm{mmol} / \mathrm{L}$ uric acid was used as standard. A standardized solution of Fe-EDTA complex reacts with hydrogen peroxide by a Fenton type reaction, leading to formation of hydroxyl radicals.

The ROS degrade benzoate, resulting in the release of TBARS Antioxidants from the added sample cause suppression of the production of TBARS. At low $\mathrm{pH}$ and elevated temperature $\left(90-100^{\circ} \mathrm{C}\right)$, MDA readily participates in nucleophilic addition reaction with 2-thiobarbituric acid (TBA), generating a red, fluorescent 1:2 MDA:TBA adduct [95]. The reaction is measured colorimetrically at $530-540 \mathrm{~nm}$ or fluorometrically at an excitation wavelength of $530 \mathrm{~nm}$ and emission wavelength of $550 \mathrm{~nm}[96,97]$

\section{HAT-based assays}

ORAC assay

ORAC assay is a method for quantifying the antioxidant strength of substances, which involves combining the sample to be tested (i.e., the antioxidant) with a fluorescent compound as well as a compound that generates free radicals at a known rate. As free radicals are being generated, the fluorescent compound (e.g., fluorescein) is damaged and subsequently loses its fluorescence.

When antioxidants are present, it mops up the free radicals being produced, and therefore, inhibits the loss of fluorescence. The stronger the antioxidant property of a substance and the higher is the degree of inhibition on the loss of fluorescence. The measurement is standardized trolox which has a known ORAC value and is reported in terms of TE ( $\mu \mathrm{M}$ TE). This method serves as an excellent way to quantify the ability of various compounds to quench free radicals. ORAC assay is carried out using a modified [98-100] procedure by comparing ORAC in vitro antioxidant activity of polyphenols with the total phenolics concentrations.

The free radicals in ORAC method are produced by $2,2^{\prime}$-azobis (2-amidino-propane) dihydrochloride (AAPH) followed by the oxidation of the fluorescent indicator protein phycoerthrin ( $\beta$-PE). The loss of fluorescence can be inhibited by antioxidants and was monitored using a microplate fluorescence reader. All reagents are prepared in phosphate buffer $(75 \mathrm{mM}), \mathrm{pH} 7.0$ with trolox $(0-4 \mu \mathrm{M})$, which is used as a standard. Before use, the samples are suitably diluted in the phosphate buffer. Quercetin dehydrate $(1 \mu \mathrm{M})$ (positive control) is dissolved in methanol followed by a dilution with buffer $(1: 249, \mathrm{v} / \mathrm{v})$. Methanol is used in the control sample, blank and standard without having an effect on the 1:1 relationship between trolox and ORAC value. The reaction mixtures consisted of $1 \mathrm{~mL}$ of $\beta$-PE $(0.92 \mathrm{nM})$ which has been pre-incubated for 15 minutes at $37^{\circ} \mathrm{C}, 60 \mu \mathrm{L}$ of test compound, $40 \mu \mathrm{L}$ of $75 \mathrm{mM}$ phosphate buffer (pH 7.0), and $100 \mu \mathrm{L}$ of AAPH (500 mM). After adding AAPH, the plate is automatically shaken for 3 seconds and the fluorescence was measured every 2 minutes for 70 minutes with emission and excitation wavelengths at 565 and $540 \mathrm{~nm}$, respectively, using a micro plate fluorescence reader FL600 (BioTek, Inc., VT), maintained at $37^{\circ} \mathrm{C}$. The ORAC values are calculated according to [98] and expressed as $\mu \mathrm{M} \mathrm{TE} / \mathrm{g}$. ANOVA with post-hoc comparisons using Tukey's test is performed to compare the ORAC readings shown by the different samples using SAS Software [101].

Utilization of a $\beta$-PE method provides an additional advantage as the substrate "self-prevents" free radical generations due to its oxidation. Therefore, it is good to determine the capacity of hydrophilic and hydrophobic samples simply by changing the generating source of radicals and the solvent. One limitation of this method is that the protein photo bleached under plate-reader conditions has large interbatch differences and interacts with polyphenols due to non-specific protein binding, and therefore, may loss fluorescence even without the addition of a free radical generator.

\section{ABTS assay}

ABTS is a measure of antioxidant activity in contrast to antioxidant concentration which includes a proportion of biologically-inactive antioxidants [102,103]. ABTS permits the measurement of antioxidant activity of mixtures of substances, hence helping to distinguish between additive and synergistic effects $[104,105]$. The original assay is based on the activation of metmyoglobin with hydrogen peroxide in the presence of ABTS to produce the radical cation either in the presence 
or absence of antioxidants. This concludes that the faster-reacting antioxidants might also contribute to the reduction of the ferryl myoglobin radical [106]. A more appropriate assay method is using a decolorization technique because the directly generated radical is stable prior to reacting with the putative antioxidants. This improved technique for the generation of ABTS involves the direct production of the blue/green ABTS chromophore via the reaction between ABTS and potassium persulfate which has absorption maxima at wavelengths $645 \mathrm{~nm}, 734 \mathrm{~nm}$, and $815 \mathrm{~nm}$ [106-108] with the more commonly used maximum absorbance reported to be at $415 \mathrm{~nm}$ [109] (Fig. 8).

The addition of antioxidants to the pre-formed radical cation reduces ABTS on a time-scale to a certain extent, depending on the antioxidant activity of the samples analyzed, the concentration of the antioxidant and the duration of each reaction. Thus, the extent of decolorization as percentage inhibition of the ABTS radical cation is determined as a function of both concentration and time and is calculated relative to the reactivity of trolox standard under similar conditions. A modification of the method utilized to determine the antioxidant capacity of was also developed [110]. For the evaluation of antioxidant activity, ABTS solution is diluted with ethanol (96\%) to obtain an absorbance of $0.700( \pm 0.020)$ at $734 \mathrm{~nm} .2 \mathrm{~mL}$ of ABTS solution are mixed with $100 \mu \mathrm{L}$ of the sample solution in a cuvette and the decrease in the absorbance is measured after 6 minutes. The reagent blank is prepared by adding $100 \mathrm{~mL}$ of ethanol instead of the sample. Ascorbic acid was used as the standard at different concentrations $(0-100 \mathrm{mg} / \mathrm{L})$ prepared in $96 \%$ ethanol and assayed under a similar procedure as that conducted on the samples with the means of the three values expressed as mg ascorbic acid equivalents $/ 100 \mathrm{~g}$.

ABTS assay is beneficial as it reduces labor time, material cost, and sample volume. A some of the assays are adapted for a more convenient mass screening using quantitative spectrophotometer as well as applied in agriculture and food industries. Although this method has been reported and commercialized by CAYMAN [111], it does not incorporate any blank samples which could result in further inaccuracies in the measurements.

CBA

Crocin $\left(\mathrm{C}_{44} \mathrm{H}_{64} \mathrm{O}_{24}\right)$ is a naturally occurring carotenoid obtained from dried stigma of culinary spice Crocus sativus L. (Saffron).

The CBA [112] is suitable for screening radical scavenging activity. Originally, an inhibition of crocin bleaching by a range of substances was monitored by competition kinetics in the presence of photolytically produced alkoxyl radicals. In CBA, abstraction of hydrogen atoms and/or addition of the radical to the polyene structure of crocin results in a disruption of the conjugated system accounting for crocin bleaching. The latter is recorded as a reduction of absorbance at $440 \mathrm{~nm}$ in the presence or absence of radical scavengers. The pro-oxidant activity was taken as a ratio of decrease in crocin absorbance at 5 minutes and the relevant oxidant concentration [113,114]. Later, Bors et al. [115] found that the absolute rate of crocin bleaching depends on the sort of radical attacking the polyene structure (Fig. 9).

In the latter, peroxyl radical formation was achieved using azo-initiators (hydrophilic or lipophilic) [116]. In this way, Tubaro et al. [117] made an effort to average antioxidant and pro-oxidant effects of the constituents of complex natural mixtures. Results were expressed with reference to $\alpha$-tocopherol (for lipophilic molecules) or trolox (for hydrophilic ones).

\section{TRAP Assay}

This method uses R-phycoerythrin (R-PE) as the fluorescent probe. The reaction progress of R-PE with AAPH was monitored fluorometrically ( $\lambda$ ex $=495 \mathrm{~nm}$ and $\lambda \mathrm{em}=575 \mathrm{~nm}$ ). R-PR is the brightest fluorescent dye identified and is originally isolated from red algae Gracilaria (Fig. 10).

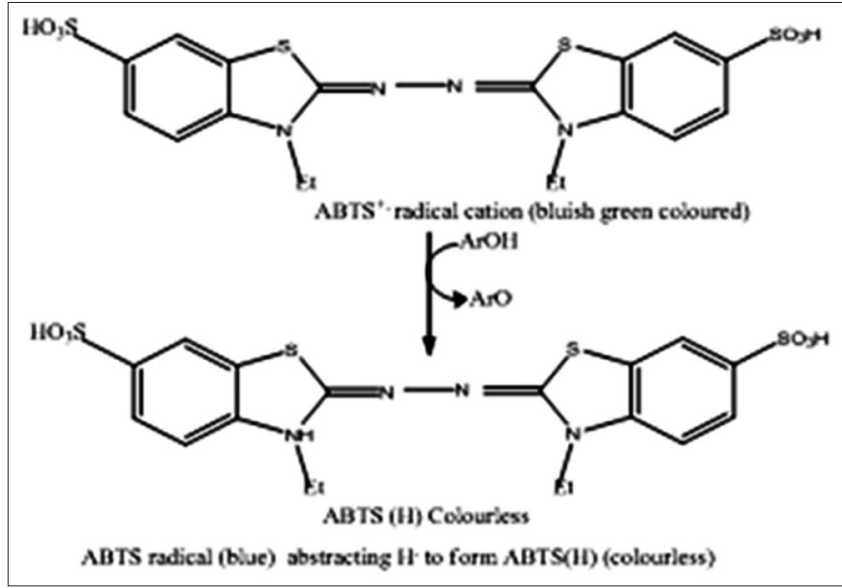

Fig. 8: 2,2-azinobis (3-ethyl benzothiazoline-6-sulfonic acid) diamonium salt reaction



Fig. 9: Crocin

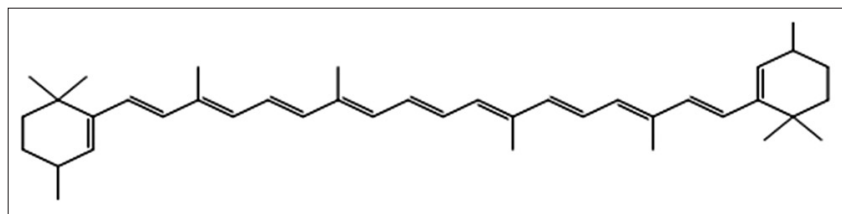

Fig. 10: R-phycoerythrin

TRAP values are calculated from the length of the lag phase caused by the antioxidant compared to that of trolox. Luminol is also used as the chemiluminescent substance [118].

Dye-substrate oxidation method

A novel microtiter plate assay was developed to determine the total peroxyl radical trapping activity of antioxidant extracted from marine organisms by measuring the inhibition rate of dye-substrate oxidation. The compared use of dihydrorhodamine-123, dihydrofluorescein, and dichlorodihydrofluorescein as reduced substrates for oxidation by peroxyl radicals generated from 2,2- azobis(2-amidinopropane) dihydrochloride. The oxidation products of these highly reactive substrates are intensely colored dyes that absorb maximally in the wavelength region, 489-512 nm, and their concentrations were determined photometrically using a 96-well, microtiter plate reader. The microtiter plate method provides concurrent multisample analysis with automated data storage, regression analyses, and calculation of oxidation inhibition rates. Dihydrorhodamine was selected as the preferred substrate for screening crude extracts, and typical assay results are presented. Novel lead antioxidants are selected from active extracts by chromatographic analysis with electrochemical detection. 
Advantages

It provides concurrent multisample analysis with automated data storage, regression analyses, and calculation of oxidation inhibition rates. For screening, crude extracts and typical assay results are presented.

\section{Hydroxyl radical scavenging activity}

Hydroxyl radical is one of the potent ROS in the biological system that reacts with polyunsaturated fatty acid moieties of cell membrane phospholipids and causes damage to cell. The scavenging ability of hydroxyl radicals is measured by the method of Kunchandy and Rao in 1990 [109]. The reaction mixture $(1.0 \mathrm{~mL})$ consist of $100 \mu \mathrm{L}$ of 2-deoxy- D-ribose (28 mM in $20 \mathrm{mM} \mathrm{KH}_{2} \mathrm{PO}_{4}$-KOH buffer, pH 7.4), $500 \mu \mathrm{L}$ of the extract, $200 \mu \mathrm{L}$ EDTA $(1.04 \mathrm{mM})$ and $200 \mu \mathrm{M} \mathrm{FeCl}_{3}(1: 1 \mathrm{v} / \mathrm{v})$, $100 \mu \mathrm{L}$ of $\mathrm{H}_{2} \mathrm{O}_{2}(1.0 \mathrm{mM})$, and $100 \mu \mathrm{L}$ ascorbic acid $(1.0 \mathrm{mM})$ which is incubated at $37^{\circ} \mathrm{C}$ for $1 \mathrm{hr} .1 \mathrm{~mL}$ of thiobarbituric acid (1\%) and $1.0 \mathrm{~mL}$ of TCA $(2.8 \%)$ are added and incubated at $100^{\circ} \mathrm{C}$ for 20 minutes. After cooling, absorbance is measured at $532 \mathrm{~nm}$, against a blank sample.

The scavenging activity for hydroxyl radicals was measured using the reaction mixture contained $60 \mu \mathrm{l}$ of $1.0 \mathrm{mM} \mathrm{FeCl}_{3}, 90 \mu \mathrm{l}$ of $1 \mathrm{mM}$ 1,10-phenanthroline, $2.4 \mathrm{ml}$ of $0.2 \mathrm{M}$ phosphate buffer ( $\mathrm{pH} 7.8$ ), $150 \mu$ of $0.17 \mathrm{M} \mathrm{H}_{2} \mathrm{O}_{2}$ and $1.5 \mathrm{ml}$ of extract at various concentrations. Adding $\mathrm{H}_{2} \mathrm{O}_{2}$ started the reaction. After incubation at room temperature for 5 minutes, the absorbance of the mixture at $560 \mathrm{~nm}$ was measured with a spectrophotometer. The hydroxyl radicals scavenging activity was calculated according to the following equation:

$\%$ inhibition $=\left[\left(A_{0}-A_{1}\right) / A_{0}\right] \times 100$

Where $A_{0}$ was the absorbance of the control (blank, without extract) and $A_{1}$ was the absorbance in the presence of the extract.

\section{HORAC}

The hydroxyl radical is generated by a $\mathrm{Co}^{2+}$ mediated Fenton-like reaction, and the hydroxyl radical formation under the experimental condition is indirectly confirmed by the hydroxylation of p-hydroxybenzoic acid. The fluorescence decay curve is monitored in the absence and presence of antioxidant which is the index of the hydroxyl radical prevention capacity. Gallic acid is chosen as a reference standard and activity is measured in terms of GAE. The hydroxyl radical prevention capacity is due to the metal-chelating capability of the compounds.

\section{Procedure}

The scavenging capacity for hydroxyl radical was determined according to the modified method [119]. The assay was performed by adding $0.1 \mathrm{ml}$ of EDTA, $0.01 \mathrm{ml}$ of ferric chloride, $0.1 \mathrm{ml}$ of hydrogen peroxide, $0.36 \mathrm{ml}$ of deoxyribose, $1.0 \mathrm{ml}$ of test solutions $(5-100 \mu \mathrm{g} / \mathrm{ml})$ in distilled water, $0.33 \mathrm{ml}$ of phosphate buffer ( $50 \mathrm{mM}, \mathrm{pH} 7.4)$, and $0.1 \mathrm{ml}$ of ascorbic acid were dissolved in sequence. Then, the mixture was incubated for $1 \mathrm{hr}$ at $37^{\circ} \mathrm{C}$ and $1.0 \mathrm{ml}$ portion of the incubated mixture was mixed with $10 \%$ TCA and $1.0 \mathrm{ml}$ of $0.5 \%$ TBA to develop the pink chromogen and measured at $532 \mathrm{~nm}$.

\section{LPIC assay}

LPO, a well-established mechanism of cellular injury in plants and animals, is used as an indicator of oxidative stress in cells and tissues. Lipid peroxides are unstable and decompose to form a complex series of compounds including reactive carbonyl compounds. Polyunsaturated fatty acid peroxides generate malondialdehyde (MDA) and 4-hydroxyalkenals (HAE) on decomposition and the measurement of MDA and HAE are used as an indicator of LPO.

The assay is based on the reaction of a chromogenic reagent, $\mathrm{N}$-methyl2-phenylindole, with MDA and $\mathrm{HAE}$ at $45^{\circ} \mathrm{C} .1$ molecule of either MDA or 4-hydroxyalkenal reacts with 2 molecules of N-methyl-2-phenylindole to yield a stable chromophore (carbocyanine dye) with maximal absorbance at $586 \mathrm{~nm}$ [120].
Procedure

Mice liver was freshly excised and processed to get $10 \%$ homogenate in cold phosphate buffered saline $(\mathrm{pH} \mathrm{7.4)}$ and clear homogenate is obtained by filtration. LPO was analyzed by estimating the TBARS using standard method with some modifications [121]. The analogues at different concentrations (25-200 $\mu \mathrm{mol} / \mathrm{l}$ in DMSO) were added to liver homogenate. LPO was initiated by adding $100 \mu \mathrm{l}$ of $15 \mathrm{mmol} / \mathrm{l}$ ferrous sulfate solution to $3 \mathrm{ml}$ tissue homogenate. After 30 minutes, $100 \mu \mathrm{l}$ of the reaction mixture was taken to a tube containing $1.5 \mathrm{ml} \mathrm{10 \%} \mathrm{TCA.}$ Tubes were centrifuged after 10 minutes and the supernatant was separated and mixed with $1.5 \mathrm{ml}$ of $0.67 \%$ TBA in $50 \%$ acetic acid The mixture was heated in boiling water bath for 30 minutes. The pink obtained was measured at $535 \mathrm{~nm}$. The results are expressed as percentage inhibition and compared with ascorbic acid

\section{Scavenging of $\mathrm{H}_{2} \mathrm{O}_{2}$ radicals}

Hydrogen peroxide scavenging activity of the extract was estimated by replacement titration [122]. Aliquot of $1.0 \mathrm{ml}$ of $0.1 \mathrm{mM} \mathrm{H}_{2} \mathrm{O}_{2}$ and $1.0 \mathrm{ml}$ of various concentrations of extracts were mixed, followed by 2 drops of $3 \%$ ammonium molybdate, $10 \mathrm{ml}$ of $2 \mathrm{M} \mathrm{H}_{2} \mathrm{SO}_{4}$ and $7.0 \mathrm{ml}$ of $1.8 \mathrm{M}$ KI. The mixed solution was titrated with $5.09 \mathrm{mM} \mathrm{NaS}_{2} \mathrm{O}_{3}$ until yellow disappeared. The percentage of scavenging of hydrogen peroxide was calculated as follows:

$\%$ inhibition $=\left[\left(\mathrm{V}_{0}-\mathrm{V}_{1}\right) / \mathrm{V}_{0}\right] \times 100$

Where $\mathrm{V}_{0}$ is the Volume of $\mathrm{NaS}_{2} \mathrm{O}_{3}$ solution used to titrate the control sample in the presence of hydrogen peroxide (without extract), $V_{1}$ is the volume of $\mathrm{NaS}_{2} \mathrm{O}_{3}$ solution used in the presence of extract.

Hydrogen peroxide is a weak oxidizing agent and inactivates a few enzymes directly, usually by oxidation of essential thiol (-SH) groups. $\mathrm{H}_{2} \mathrm{O}_{2}$ crosses cell membranes rapidly, once inside the cell, $\mathrm{H}_{2} \mathrm{O}_{2}$ can probably react with $\mathrm{Fe}^{2+}$, and possibly $\mathrm{Cu}^{2+}$ ions to form hydroxyl radical and this leads to many of its toxic effects. It is therefore biologically advantageous for cells to control the amount of $\mathrm{H}_{2} \mathrm{O}_{2}$ that is allowed to accumulate. The extract inhibits $\mathrm{H}_{2} \mathrm{O}_{2}$ in dose-dependent manner. The $\mathrm{IC}_{50}$ of the extracts were determined.

\section{IOC/total oxidant scavenging capacity (TOSC)}

This method [123] permits quantification of the absorbance capacity of antioxidants specifically toward three potent oxidants, that is, hydroxyl radicals, peroxyl radicals, and peroxynitrite [124]. It evaluates different antioxidants with different biologically relevant radical sources. The substrate that is oxidized in this assay is R-keto- $\gamma$-methiolbutyric acid, forms ethylene. The time course of ethylene formation is followed by headspace analysis of the reaction cell by gas chromatography, and the antioxidant capacity is quantified by the ability of the antioxidant to inhibit ethylene formation relative to a control reaction. The method uses an area under the curve that best defines the experimental points during the reaction time, which can be up to 300 minutes. Linear dose-response curves for antioxidants are generated from kinetics of the reaction.

\section{Advantages of the TOSC assay}

It permits the quantification of the antioxidant capacity toward three oxidants, that is, hydroxyl radicals, peroxyl radicals, and peroxynitrite.

\section{Disadvantages}

The method is not adaptable for high-throughput analyses required for quality control in that it requires multiple injections from a single sample into a gas chromatograph to measure the production of ethylene. The kinetics of the TOSC assay concludes that there is no linear relationship between the percentage inhibition of TOSC by the antioxidant source and antioxidant concentration or dilution [125]. Thus, calculated dilution factors for $20 \%, 50 \%$, and $80 \%$ TOSC are determined, and a $\mathrm{DT}_{50}$ is calculated, which is the first derivative of the dose-response curve at a TOSC of $50 \%$. Comparison between foods becomes difficult because of these multiple endpoint parameters. 


\section{PCL assay}

In the PCLassay, the photochemicalgeneration of free radicals is combined with the sensitive detection using chemiluminescence [126,127]. The reaction is induced by optical excitation of a photosensitiser $\mathrm{S}$, which results in the generation of the superoxide radical $\mathrm{O}_{2}{ }^{--}$.

$\mathrm{S}+\mathrm{hu}+\mathrm{O}_{2} \rightarrow\left[\mathrm{S}^{*} \mathrm{O}_{2}\right] \rightarrow \mathrm{S}^{\cdot+}+\mathrm{O}_{2}^{\cdot-}$

The free radicals are visualized with a chemiluminescent detection reagent. Luminol (5-amino-2, 3-dihydro-1,4-phthalazinedione) acts as photosensitiser and oxygen radical detection reagent. Luminol on excitation gives $\mathrm{L}^{*}$ an intermediate and triplet oxygen ${ }^{3} \mathrm{O}_{2}$. Once the $\mathrm{O}_{2}{ }^{--}$and luminol radicals are generated, they proceed through a series of reactions resulting in the production of blue luminescence. In the presence of any exogenous antioxidant species the $\mathrm{O}_{2}{ }^{--}$radical out compete the luminal radical via a HAT reaction leading to halt in luminescence until the concentration of antioxidant is exhausted. The resultant lag/log relationships of antioxidant compounds are compared with an effectiveness of standards.

\section{Procedure}

A value of $1.5 \mathrm{ml}$ of buffer solution of $\mathrm{pH} 10.5,1 \mathrm{ml}$ of distilled water, $25 \mu \mathrm{l}$ of photo sensitizer, and $10 \mu \mathrm{l}$ of standard solution was mixed and measured; the antioxidant potential was assayed using the lag phase at different concentrations.

\section{$\beta$-carotene-linoleic acid (linoleate) assay/conjugated diene assay}

In the $\beta$-carotene-linoleic acid coupled oxidation model system, the linoleic acid free radical (LOO') formed attacks the highly unsaturated $\beta$-carotene molecules. In the absence of an antioxidant rapidly bleaches the typically orange of $\beta$-carotene which is monitored spectrophotometrically at $450 \mathrm{~nm}$. The extracts reduced the extent of $\beta$-carotene bleaching by neutralising the linoleate-free radical and other free radicals formed in the system [128].

A solution of $\beta$-carotene was prepared by dissolving $2 \mathrm{mg}$ of $\beta$-carotene in $10 \mathrm{ml}$ of chloroform. $2 \mathrm{~mL}$ of the solution were pipetted into a $100 \mathrm{ml}$ round-bottom flask. After chloroform was removed under vacuum, using a rotary evaporator at $40^{\circ} \mathrm{C}, 40 \mathrm{mg}$ of purified linoleic acid, $400 \mathrm{mg}$ of Tween 40 emulsfier, and $100 \mathrm{ml}$ of aerated distilled water were added to the flask with vigorous shaking. Aliquots $(4.8 \mathrm{ml})$ of this emulsion were transferred into a series of tubes con-taining 100 or $200 \mathrm{ml}$ of the extract (in methanol) so that the final concentrations of the extract in the assay media were 100 and $200 \mathrm{ppm}$. The total volume of the systems was adjusted to $5 \mathrm{ml}$ with methanol. BHA and trans-sinapic acid were used for comparative purposes. As soon as the emulsion was added to each tube, the zero time absorbance was measured at $470 \mathrm{~nm}$ using a Hew-Let Packard diode array spectrophotometer (Model 8452A, Hewlett-Packard Co., Mississauga, ON). Sub-sequent absorbance readings were recorded over a 2 -hr period at 15 minutes intervals by keeping the samples in a water bath at $50^{\circ} \mathrm{C}$. Blank samples, devoid of $\beta$-carotene, were prepared for background subtraction [129]. Antioxidant index (AI) was calculated using the following equation:

$\mathrm{Al}=(\beta$-carotene content after $2 \mathrm{hr}$ of assay/initial $\beta$-carotene content) $\times 100$

This is a rapid method to screen antioxidants, which is mainly based on the principle that linoleic acid (an unsaturated fatty acid), gets oxidized by "ROS" produced by oxygenated water. The products formed will initiate the $\beta$-carotene oxidation, which will lead to discoloration. Antioxidants decrease the extent of discoloration, which is measured at $434 \mathrm{~nm}$ and the activity is measured.

\section{Procedure}

$\beta$-carotene $(0.5 \mathrm{mg})$ in $1 \mathrm{~mL}$ of chloroform is added to $25 \mathrm{lL}$ of linoleic acid and $200 \mathrm{mg}$ of tween-80 emulsified mixture. Chloroform is evaporated at $40^{\circ} \mathrm{C}, 100 \mathrm{~mL}$ of distilled water saturated with oxygen is slowly added to the residue and the solution is vigorously agitated to form a stable emulsion. $4 \mathrm{~mL}$ of this mixture is added into the test tubes containing $200 \mathrm{lL}$ of sample prepared in methanol at final concentrations $(25,50,100,200$ and $400 \mu \mathrm{g} / \mathrm{mL})$. Immediately, as soon as the emulsified solution is added to the tubes, zero time absorbance is measured at $470 \mathrm{~nm}$. The tubes are incubated for $2 \mathrm{hr}$ at $50^{\circ} \mathrm{C}$. Vitamin C is used as standard.

\section{Other in vitro antioxidant methods \\ Ascorbic acid content assay}

Determination of ascorbate by high performance liquid chromatography (HPLC) is based on the methods developed by Lee and Coates [130]. Triplicate extracts are prepared by diluting $5 \mathrm{~g}$ of sample to $10 \mathrm{~mL}$ with dithiothreitol solution (4.2 mM in $0.1 \mathrm{M} \mathrm{K}_{2} \mathrm{HPO}_{4}, \mathrm{pH} 7.0$ ) followed by a through mixing. In this test, $1 \mathrm{~mL}$ of extract and $1 \mathrm{ml}$ of $4.5 \%$ m-phosphoric acid are mixed followed by a $20 \mu \mathrm{L}$ injection into the HPLC system [100]. The stationary phase of the HPLC is a $150 \mathrm{~mm}$; $3.9 \mathrm{~mm}$ i.d., $5 \mu \mathrm{M}$ XTerra $\mathrm{RP}_{18}$ (Waters, $\mathrm{MA}$ ) column. A linear gradient is generated using $50 \mathrm{mM} \mathrm{KH}_{2} \mathrm{PO}_{4}(\mathrm{pH} 4.5)$ (solvent $\mathrm{A}$ ) and methanol (solvent $\mathrm{B}$ ) starting at $100 \% \mathrm{~A}$ and decreasing to $70 \% \mathrm{~A}$ in 8 minutes. The selected flow rate was $0.8 \mathrm{~mL} /$ minutes with detection done at $263 \mathrm{~nm}$.

\section{Cellular antioxidant activity (CAA)}

In vitro CAA can be assessed using a Light-Scattering Properties (turbidity) of Human Erythrocytes. It relies on differences in scattering properties between lysed and intact human erythrocytes. AAPH, a peroxyl radical generator is used to enhance LPO. The consequent hemolysis triggered a loss of the light-scattering ability in the lysed erythrocytes. When an antioxidant is added, the area under the absorbance decay curve was linearly proportional to the concentration of the antioxidant compound.

\section{Modification}

The erythrocyte CAA (ERYCA) method is found to be relatively fast, sensitive, accurate, and repeatable, when using erythrocytes from different donors and for different storage times [131]. The ERYCA assay has the advantage of assessing different mechanisms of antioxidant protection including direct scavenging of free radicals in the surrounding medium and cell-mediated antioxidant protection (CellMAP), in one step.

Cell-MAP addresses the following: The physiochemical properties of antioxidants such as their lipo-solubility, the ability of both lipid and water-soluble compounds to diffuse effectively into lipoproteins and cell membranes and eventually enhance from there, the erythrocytes defenses through mediation of both, plasma membrane redox system, and the antioxidative defense enzyme system [132].

\section{Electron paramagnetic resonance (EPR) spectroscopy investigations}

To test the antioxidant efficacy of the prepared plant extracts, to generate the hydroxyl radical (HO'), the Fenton (Haber-Weiss) reaction was used. Ferrous sulfate reacts with hydrogen peroxide in the following manner:

$\mathrm{Fe}^{2+}+\mathrm{H}_{2} \mathrm{O}_{2} \rightarrow \mathrm{Fe}^{3+}+\mathrm{HO}^{-}+\mathrm{HO}^{-}$

The generated $\mathrm{HO}^{*}$ radical reacts rapidly with either the added antioxidant or the nitrogenic spin trap, 5,5-dimethyl-1-pyrroline


stable spin trap that is detectable by EPR spectroscopy [133]. DMPO and $\mathrm{H}_{2} \mathrm{O}_{2}$ were prepared in a $0.1 \mathrm{M}$ phosphate buffer, $\mathrm{pH} 7.2$, while ferrous sulfate and plant extracts were dissolved in distilled water [134]. The control reaction mixture consisted of $20 \mathrm{ml}$ each of $0.3 \mathrm{M} \mathrm{DMPO}, 10 \mathrm{mM} \mathrm{H}_{2} \mathrm{O}_{2}, 10 \mathrm{mM}$ ferrous sulfate and water, to give final concentrations of $0.075 \mathrm{M} \mathrm{DMPO}, 2.5 \mathrm{mM} \mathrm{H}_{2} \mathrm{O}_{2}$ and $2.5 \mathrm{mM}$ 
ferrous sulfate. For test samples, the water was replaced by $20 \mathrm{ml}$ of extract solutions containing $0.5,1.0,2.0$ and 4.0-mg quantities. A half of the test mixture was transferred to a capillary tube: The capillary containing the sample in air was sealed with a silicone sealant (Dow Corning high vacuum grease), put into an EPR quartz tube $(159 \mathrm{~mm}$ length, $3.00 \mathrm{~mm}$ o.d., $2.04 \mathrm{~mm}$ i.d. Wilmad Glass, Buena, NJ), and then scanned by the EPR spectrometer exactly 3 minutes after ferrous sulfhate had been added to the sample. The EPR scan was completed 14 minutes later. The EPR measurements of the free radicals were performed using an X-band continuous-wave ( $\mathrm{n}=9.4 \mathrm{GHz}$ ) Bruker ESP-300 spectrometer equipped with a Bruker ER-4107 WZ high-sensitivity resonator. Operating parameters for the EPR spectrometer were as follows: Microwave power $10 \mathrm{~mW}$ center field $3340 \mathrm{G}$, sweep width $70.0 \mathrm{G}$, conversion time $163.84 \mathrm{~ms}$, time constant $81.92 \mathrm{~ms}$, modulation frequency $50 \mathrm{kHz}$, modulation amplitude usually, 5 scans per sample, and a temperature of $22^{\circ} \mathrm{C} \pm 1^{\circ} \mathrm{C}$. All scans were recorded using the same instrument settings and sample position and were carried out in diffuse room light. For any given type of experiment, three sample preparations were recorded. The magnetic-field values of all experimental EPR spectra were adjusted by measuring a sample of $0.1 \mathrm{mM}$ DPPH in benzene under identical conditions to those for the spin-adduct samples. The magnetic field was corrected according to the known $g$ value of 2.00354 for DPPH [135]. The difference between fields at the location of the proton NMR gaussmeter and the sample of interest was calculated. Thus, the position of each EPR line obtained from the samples analyzed was adjusted. To simulate the experimental EPR spectrum, the computer programs, WinSim and EPR-NMR were used [136,137]. Each simulated spectrum consists of the first derivative intensity values plotted against 4096 points of magnitude of the corrected applied magnetic field. The relevant spectroscopic parameters, namely, the g value, hyperfine coupling constants, and line widths were employed in the production of a plot so that correct identification of the free radicals could be determined.

\section{Phosphomolybdenum assay [138]}

The antioxidant capacity by phosphomolybdenum assay can be assessed by the reduction of molybdenum to a green molybdenum complex by the antioxidant compounds present in the plant extracts [133].

\section{Procedure}

A amount of $1 \mathrm{~mL}$ of reagent solution $\left(0.6 \mathrm{M} \mathrm{H}_{2} \mathrm{SO}_{4}, 28 \mathrm{mM} \mathrm{Na}_{3} \mathrm{PO}_{4}\right.$ and $\left.4 \mathrm{mM}\left(\mathrm{NH}_{4}\right)_{2} \mathrm{MoO}_{4}\right)$ and $0.1 \mathrm{ml}$ of sample solution. The samples were incubated at $95^{\circ}$ for 90 minutes by capping them with silver foil. After incubation the tubes were cooled to room temperature and absorbance was measured at $695 \mathrm{~nm}$ against blank. Ascorbic acid was used as standard. Total antioxidant activity was expressed nM GAE/g of dry extract.

\section{Xanthine oxidase method}

The xanthine oxidase activity with xanthine as sub-substrate can be measured spectrophotometrically by the method of Noro et al. [139]. The extract (500 lL of $0.1 \mathrm{mg} / \mathrm{mL}$ ) and allopurinol $(100 \mathrm{lg} / \mathrm{mL}$ ) (in methanol) are mixed with $1.3 \mathrm{~mL}$ phosphate buffer $(0.05 \mathrm{M}, \mathrm{pH} 7.5)$ and $0.2 \mathrm{~mL}$ of 0.2 units $/ \mathrm{mL}$ xanthine oxidase solution. After 10 minutes of incubation at room temperature $\left(25^{\circ} \mathrm{C}\right), 1.5 \mathrm{~mL}$ of $0.15 \mathrm{M}$ xanthine substrate solution is added to the mixture. The mixture is again incubated for 30 minutes at room temperature $\left(25^{\circ} \mathrm{C}\right)$, and then the absorbance is measured at $293 \mathrm{~nm}$ using a spectrophotometer against blank $(0.5 \mathrm{~mL}$ methanol, $1.3 \mathrm{~mL}$ phosphate buffer, $0.2 \mathrm{~mL}$ xanthine oxidase). The solution of $0.5 \mathrm{~mL}$ methanol, $1.3 \mathrm{~mL}$ phosphate buffer $0.2 \mathrm{~mL}$ xanthine oxidase, and $1.5 \mathrm{~mL}$ xanthine substrate is used as a control. \% inhibition is calculated using the formula:

$\%$ inhibition=[1-(As/Ac) $] \times 100$

Where: As and Ac are the absorbance values of the test sample and control, respectively.

\section{Metal chelating activity}

Ferrozine forms a red colored complex by forming chelates with $\mathrm{Fe}^{2+}$. This reaction is restricted in the presence of other chelating agents and results in a decrease of the red of the ferrozine- $\mathrm{Fe}^{2+}$ complexes. A measurement of the color reduction determines the chelating activity to compete with ferrozine for the ferrous ions [140]. The chelation of ferrous ions is estimated using the method [141] of Dinis et al. $0.1 \mathrm{~mL}$ of the extract is added to a solution of $0.5 \mathrm{~mL}$ ferrous chloride $(0.2 \mathrm{mM})$. The reaction is started by the addition of $0.2 \mathrm{~mL}$ of ferrozine $(5 \mathrm{mM})$ and incubated at room temperature for 10 minutes and then the absorbance was measured at $562 \mathrm{~nm}$. EDTA or citric acid is used as a positive control.

\section{In vivo antioxidant activity (Table 2)}

For all in vivo methods, the samples that are to be tested are usually administered to the testing animals (mice, rats, etc.) at a definite dosage regimen as described by the respective method. After a specified period of time, the animals are usually sacrificed and blood or tissues are used for the assay.

\section{FRAP}

It is one of the most rapid tests and very useful for routine analysis [142] The antioxidative activity is estimated by measuring the increase in absorbance caused by the formation of ferrous ions from FRAP reagent containing TPTZ and $\mathrm{FeCl}_{2} \cdot 6 \mathrm{H}_{2} \mathrm{O}$. The absorbance is measured spectrophotometrically at $593 \mathrm{~nm}$.

\section{Procedure [143]}

Blood samples are collected from the rat retroorbital venous plexus into heparinized glass tubes at 0,7 and 14 days of treatment. $3 \mathrm{~mL}$ of freshly prepared and warm $37^{\circ} \mathrm{C}$ FRAP reagent $(1 \mathrm{~mL}(10 \mathrm{mM})$ of TPTZ solution in $40 \mathrm{mM} \mathrm{HCl}, 1 \mathrm{~mL} 20 \mathrm{mM} \mathrm{FeCl}_{2} \cdot 6 \mathrm{H}_{2} \mathrm{O}, 10 \mathrm{~mL}$ of $0.3 \mathrm{M}$ acetate buffer [pH 3.6]) is mixed with $0.375 \mathrm{~mL}$ distilled water and $0.025 \mathrm{~mL}$ of test samples. The absorbance of developed color in organic layer is measured at $593 \mathrm{~nm}$. The temperature is maintained at $37^{\circ} \mathrm{C}$. The readings at $180 \mathrm{~S}$ are selected for the calculation of FRAP values.

\section{Reduced GSH estimation}

GSH is an intracellular reductant and plays a major role in catalysis, metabolism, and transport. It protects cells against free radicals, peroxides, and other toxic compounds [144]. Deficiency of GSH in the lens leads to cataract formation. GSH also plays an important role in the kidney and takes part in a transport system involved in the reabsorption of amino acids. The method illustrated by Ellman [145] is used for determination of antioxidant activity. The tissue homogenate (in $0.1 \mathrm{M}$ phosphate buffer $\mathrm{pH} 7.4$ ) is taken and added with equal volume of $20 \%$ TCA containing $1 \mathrm{mM}$ EDTA to precipitate the tissue proteins. The mixture is allowed to stand for 5 minutes prior to centrifugation for

Table 2: List of in vivo anti-oxidant methods

\begin{tabular}{lc}
\hline Serial number & Name of the antioxidant method \\
\hline 2. & In vivo antioxidant methods \\
2.1. & Ferric reducing ability of plasma \\
2.2. & Reduced GSH estimation \\
2.3. & GSHpx estimation \\
2.4. & GSt \\
2.5. & SOD method \\
2.6. & CAT \\
2.7. & GGT assay \\
2.8. & GSR assay \\
2.9. & LPO assay \\
2.10. & LDL assay \\
2.11. & CAA assay \\
\hline
\end{tabular}

GSH: Glutathione, GSHpx: Glutathione peroxidase,

GSt: Glutathione-S-transferase, SOD: Superoxide dismutase, CAT: Catalase GGT: $\gamma$-glutamyl transpeptidase activity, GSR: Glutathione reductase, LPO: Lipid peroxidation, LDL: Low-density lipoprotein, CAA: Cellular antioxidant activity 
10 minutes at $2000 \mathrm{rpm}$. The supernatant $(200 \mathrm{lL}$ ) is then transferred to a new set of test tubes and added with $1.8 \mathrm{~mL}$ of the Ellman's reagent (5,50-dithiobis-2-nitrobenzoic acid $(0.1 \mathrm{mM})$ prepared in 0.3 M phosphate buffer with $1 \%$ of sodium citrate solution). Then all the test tubes are made up to the volume of $2 \mathrm{~mL}$. After completion of the total reaction, solutions are measured at $412 \mathrm{~nm}$ against blank. The absorbance values were compared with a standard curve generated from known GSH.

\section{GSHPx estimation}

GSHPx is a selenoenzyme two-third of which (in liver) is present in the cytosol and one-third in the mitochondria. It catalyzes the reaction of hydroperoxides with reduced GSH to form GSH disulfide (GSSG) and the reduction product of hydroperoxide. GSHPx is found throughout the tissues, being present as four different isoenzymes, cellular GSHpx, extracellular GSHpx, phospholipid hydroperoxide GSHpx and gastrointestinal GSHpx. GSHPx measurement is considered in particular with patients who are under oxidative stress for any reason; the low activity of this enzyme is one of the early consequences of a disturbance of the prooxidant/antioxidant balance [146,147]. According to wood [148], cytosolic GPx is assayed via a 3-mL cuvette containing $2.0 \mathrm{~mL}$ of $75 \mathrm{mM} / \mathrm{L}$ phosphate buffer, $\mathrm{pH}$ 7.0. The following solutions are then added: $50 \mathrm{lL}$ of $60 \mathrm{mM} / \mathrm{L}$ GSR solution $(30 \mathrm{U} / \mathrm{mL})$ $50 \mathrm{lL}$ of $0.12 \mathrm{M} / \mathrm{L} \mathrm{NaN}_{3}, 0.10$ of $0.15 \mathrm{mM} / \mathrm{L} \mathrm{Na}{ }_{2}$ EDTA, $100 \mathrm{lL}$ of $3.0 \mathrm{mM} / \mathrm{L}$ $\mathrm{NADPH}$, and $100 \mathrm{lL}$ of cytosolic fraction obtained after centrifugation at $20,000 \mathrm{~g}$ for 25 minutes. Water is added to make a total volume of $2.9 \mathrm{~mL}$. The reaction is started by the addition of $100 \mathrm{lL}$ of $7.5 \mathrm{mM} / \mathrm{L} \mathrm{H}_{2} \mathrm{O}_{2^{\prime}}$ and the conversion of NADPH to NADP is monitored by a continuous recording of the change of absorbance at $340 \mathrm{~nm}$ at 1 minute interval for 5 minutes. Enzyme activity of GSHPx was expressed in terms of mg of proteins.

\section{GSt}

GSt is thought to play a physiological role in initiating the detoxication of potential alkylating agents including pharmacologically active compounds. These enzymes catalyze the reaction of such compounds with the -SH group of GSH, thereby neutralizing their electrophilic sites and rendering the products more water-soluble.

The method can be used as described by Jocelyn [149]. The reaction mixture $(1 \mathrm{~mL})$ consisted of $0.1 \mathrm{~N}$ potassium phosphate $(\mathrm{pH} 6.5)$, $1 \mathrm{nM} / \mathrm{L}$ GSt, $1 \mathrm{M} / \mathrm{L}$ l-chloro-2, 4-dinitrobenzene as substrate and a suitable amount of cytosol ( $6 \mathrm{mg}$ protein $/ \mathrm{mL}$ ). The reaction mixture is incubated at $37^{\circ} \mathrm{C}$ for 5 minutes and the reaction is initiated by the addition of the substrate. The increase in absorbance at $340 \mathrm{~nm}$ was measured spectrophotometrically.

\section{SOD method}

This method is well described by Mccord and Fridovich [150] and can be applied for the determination of antioxidant activity of a sample. It is estimated in the erythrocyte lysate prepared from the $5 \% \mathrm{RBC}$ suspension. To $50 \mathrm{lL}$ of the lysate, $75 \mathrm{mM}$ of Tris- $\mathrm{HCl}$ buffer ( $\mathrm{pH}$ 8.2), $30 \mathrm{mM}$ EDTA and $2 \mathrm{mM}$ of pyrogallol are added. An increase in absorbance is recorded at $420 \mathrm{~nm}$ for 3 minutes by spectrophotometer. One unit of enzyme activity is $50 \%$ inhibition of the rate of autooxidation of pyrogallol as determined by change in absorbance/minutes at $420 \mathrm{~nm}$. The activity of SOD is expressed as units/mg protein.

\section{CAT}

CAT activity can be determined in erythrocyte lysate using Aebi's method [151]. $50 \mu \mathrm{L}$ of the lysate is added to a cuvette containing $2 \mathrm{~mL}$ of phosphate buffer ( $\mathrm{pH} \mathrm{7.0)}$ and $1 \mathrm{~mL}$ of $30 \mathrm{mM} \mathrm{H}_{2} \mathrm{O}_{2}$. CAT activity is measured at $240 \mathrm{~nm}$ for 1 minute using spectrophotometer. The molar extinction coefficient of $\mathrm{H}_{2} \mathrm{O}_{2}, 43.6 \mathrm{M} / \mathrm{cm}$ was used to determine the CAT activity. One unit of activity is equal to $1 \mathrm{mmol}$ of $\mathrm{H}_{2} \mathrm{O}_{2}$ degraded per minute and is expressed as units per milligram of protein.

\section{$\gamma$-Glutamyl transpeptidase activity (GGT) assay}

According to Singhal et al. [152], the serum sample is added to a substrate solution containing glycylglycine, $\mathrm{MgCl}_{2}$ and g-glutamyl-pnitroanilide in $0.05 \mathrm{M}$ tris (free base), $\mathrm{pH}$ 8.2. The mixture is incubated at $37^{\circ} \mathrm{C}$ for 1 minute and the absorbance read at $405 \mathrm{~nm}$ at $1 \mathrm{~m}$ interval for $5 \mathrm{~m}$. The activity of GGT is calculated from the absorbance values.

\section{GSR assay}

The ubiquitous tripeptide GSH, which is the most abundant low molecular weight thiol in almost all cells, is involved in a wide range of enzymatic reactions. A major function of GSH is to serve as a reductant in oxidation-reduction processes; a function resulting in the formation of GSH disulfide (GSSG). A heat labile system capable of reducing GSSG was discovered in liver. The enzyme directly involved in the reduction of GSSG. In this method [153], livers (about $400 \mathrm{~g}$ ) are obtained from killed rats (200-250 g). The livers are cut into small pieces and homogenized in $9 \mathrm{~mL}$ of $0.25 \mathrm{M}$ ice-cold sucrose per $\mathrm{g}$ of rat liver in a blender. The homogenate is centrifuged for 45 minutes at $14,000 \mathrm{rpm}$. The pellets are suspended in a small volume of $0.25 \mathrm{M}$ sucrose and centrifuged. The supernatants are combined with the previous centrifugate. The pooled material is adjusted to $\mathrm{pH} 5.5$ with cold $0.2 \mathrm{M}$ acetic acid and centrifuged again for 45 minutes at $14,000 \mathrm{rpm}$. The rate of oxidation of NADPH by GSSG at $30^{\circ} \mathrm{C}$ is used as a standard measure of enzymatic activity. The reaction system of $1 \mathrm{~mL}$ contained: $1.0 \mathrm{mM}$ GSSG, $0.1 \mathrm{mM}$ NADPH, $0.5 \mathrm{mM}$ EDTA, 0.10M sodium phosphate buffer (pH 7.6), and a suitable amount of the GSR sample to give a change in absorbance of $0.05-0.03 /$ minutes. The oxidation of $1 \mathrm{lM}$ of NADPH/minutes under these conditions is used as a unit of GSR activity. The specific activity is expressed as units per mg of protein.

\section{LPO assay}

LPO is an autocatalytic process, which is a common consequence cell death. This process causes peroxidative tissue damage in inflammation, cancer and toxicity of xenobiotics and aging. MDA is one of the end products in the LPO process. MDA is formed during oxidative degeneration as a product of free oxygen radicals, which is accepted as an indicator of LPO. In this method [154], the tissues are homogenized in $0.1 \mathrm{M}$ buffer $\mathrm{pH} 7.4$ with a Teflon glass homogenizer. LPO in this homogenate is determined by measuring the amounts of MDA produced primarily. Tissue homogenate $(0.2 \mathrm{~mL}), 0.2 \mathrm{~mL}$ of $8.1 \%$ sodium dodecyl sulfate, $1.5 \mathrm{~mL}$ of $20 \%$ acetic acid, and $1.5 \mathrm{~mL}$ of $8 \%$ TBA are added. The volume of the mixture is made up to $4 \mathrm{~mL}$ with distilled water and then heated at $95^{\circ} \mathrm{C}$ on a water bath for 60 minutes using glass balls as condenser. After incubation the tubes are cooled to room temperature and final volume was made to $5 \mathrm{~mL}$ in each tube. $5 \mathrm{~mL}$ of butanol:pyridine $(15: 1)$ mixture is added and the contents are vortexed thoroughly for 2 minutes. After centrifugation at $3000 \mathrm{rpm}$ for 10 minutes, the upper organic layer is taken and its OD is taken at $532 \mathrm{~nm}$ against an appropriate blank without the sample. The levels of lipid peroxides are expressed as n moles of TBARS/mg protein using an extinction coefficient of $1.56 \times 10^{5} \mathrm{~mL} / \mathrm{cm}$.

\section{Low-density lipoprotein (LDL) assay}

The isolated LDL is washed and dialyzed against $150 \mathrm{mmol} / \mathrm{L} \mathrm{NaCl}$ and $1 \mathrm{mmol} / \mathrm{L} \mathrm{Na} \mathrm{EDTA}_{2} \mathrm{pH} \mathrm{7.4)}$ at $4^{\circ} \mathrm{C}$. The LDL is sterilized by filtration $(0.45 \mu \mathrm{M})$, kept under nitrogen in the dark at $4^{\circ} \mathrm{C}$. LDL $(100 \mu \mathrm{g}$ of protein $/ \mathrm{mL}$ ) is incubated for 10 minutes at room temperature with samples. Then, $5 \mathrm{lmol} / \mathrm{L}$ of $\mathrm{CuSO}_{4}$ is added, and the tubes are incubated for $2 \mathrm{hr}$ at $37^{\circ} \mathrm{C} . \mathrm{Cu}^{2+}$ induced oxidation is terminated by the addition of BHT (BHT, $10 \mathrm{lM}$ ). At the end of the incubation, the extent of LDL oxidation is determined by measuring the generated amount of lipid peroxides and also by the TBARS assay at $532 \mathrm{~nm}$, using MDA for the standard curve $[155,156]$.

\section{CAA assay}

CAA model represents the complexity of biological systems and is an important tool for screening foods, phytochemicals and dietary 
supplements for potential biological activity. Many of the chemical assays are performed at nonphysiological $\mathrm{pH}$ and temperature and therefore be unreliable indicators of true biological antioxidant levels.

The technique accounts for uptake, metabolism, and distribution of antioxidant compounds within cells and it provides a clearer picture of how the antioxidants act within a living cell (in vivo) and by extension, a living cell culture rather than in a test tube (in vitro). This method is very expensive and is not suitable for initial antioxidant screening of foods and dietary supplements.

Since the liver is the major place for xenobiotic metabolism therefore liver cells can be used as model cells for determination of oxidative stress in cultured cells for evaluation of chemoprotective effect of dietary compounds. Human $\mathrm{HepG}_{2}$, a differentiated cell line of hepatic origin is used as reliable model for such assays [157]. The CAA method is a cell-based assay that loads a cell with the diacetate precursor of an indicator compound, 2,7-dichlorofluorescin (DCFH), i.e., DCFH-DA which is oxidized to DCF when ROS such as peroxyl radicals are present. The concentration of DCF, a fluorescent compound, can be measured using a fluorescent plate reader. The assay involves the use of peroxyl radicals generated from azobis (amidinopropane) dihydrochloride.

When a sample of phytochemical origin such as fruit or vegetable extract or dietary supplements containing antioxidants is added to the assay, the antioxidants react with the peroxyl radicals, preventing the peroxyl radicals from oxidizing the DCFH, and prevent the formation of DCF Consequently, the fluorescence decreases due to the scavenging effects of the antioxidants. For example, vitamins, carotenoids, phenolics, and flavonoids [158].

\section{RESULTS AND DISCUSSION}

By compilation of various methods of antioxidant activity, the frequency of each method is being reported. The results of the said frequency analysis for in vitro and in vivo methods are shown in Figs. 11 and 12, respectively. Antioxidants act by several mechanisms and no one assay can capture the different modes of action of antioxidant.

It is clear from Fig. 11 that four in vitro methods were the most frequently used, and these were in order of decreasing frequency: DPPH $>$ Hydroxyl radical scavenging $>$ SOD $>\beta$-carotene linolate. Out of all the in vitro methods, DPPH is the most easy, simple method, and hence, it might have been used mostly for the antioxidant activity evaluation of a sample.

From the Fig. 12, among the in vivo methods, it appears that the frequency of use is higher for LPO assay and it was followed by CAT and GSHPx. A lipid is a major component of cell membrane and thus its peroxidation almost directly co-relates peroxidative damage of cell in vivo, and hence, it might have been found to have the highest frequency in vivo antioxidant activity assay.

Fig. 13 represents the frequency of use of solvent for the extraction of material to evaluate its antioxidant property. It is evident from the Fig. 13 that four solvents are prominently being used for the extraction purpose in relation to the stated experiment. These solvents are ethanol, water, methanol, and aqueous ethanol. Ethanol, methanol, and water have a good polarity and hence are used favorably to extract polar compounds such as phenolic compounds and flavonoids which are believed to be effective antioxidants. Ethanol being organic and nontoxic might have the highest frequency of use for extraction purpose. Water needs a different step of freeze drying to remove it from the extract after extraction. Toxicity of methanol limits its use in some extraction and subsequent experiment. Non-polar solvents such as ether and low polarity solvents such as chloroform, ester, and acetone have been used in specific cases, and their availability also limits their use in the experiment and hence their frequency of use was found very low.



Fig. 11: Frequency of commonly used in vitro methods

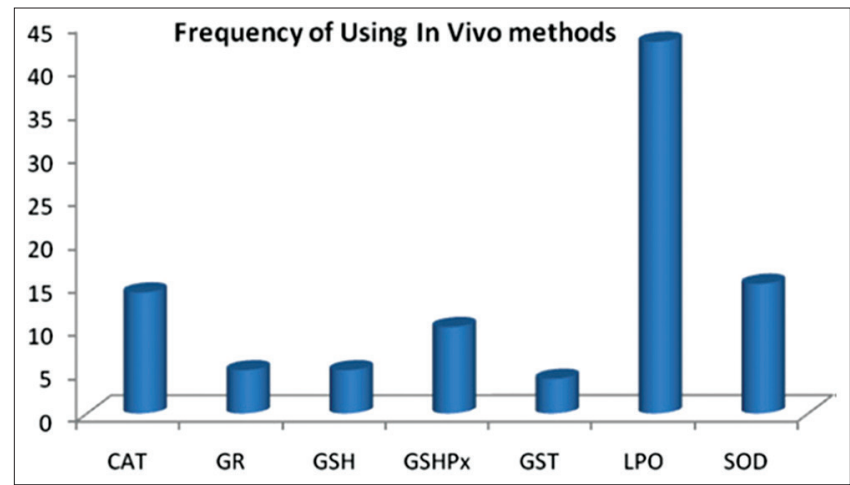

Fig. 12: Frequency of commonly used in vivo methods



Fig. 13: Commonly used extracting solvents for antioxidant study

\section{CONCLUSION}

The antioxidant properties are contributed by the presence of polyphenolics, flavonoids, vitamin $\mathrm{C}$, and monophenolics making the identification and quantification of these compounds important.

A range of analytical methods is available for the determination of antioxidant properties. Our review clearly demonstrates that different assay methods differ from one another in terms of reaction mechanisms, oxidant species, reaction conditions, and the way the final results were expressed. It is hoped that the summarized information on the various methods available for antioxidant determination provides the scientific community with reliable information to confirm the benefits of antioxidant effects and helps to provide some basic information 
before a more expensive and time-consuming effort of identification and characterization of the antioxidant components.

As a conclusion, the use of DPPH assay coupled with various other useful methods such as FRAP and ORAC, preferred because they are able to reflect the antioxidant properties more accurately.

\section{REFERENCES}

1. Tiwari AK. Antioxidants: New generation therapeutic base for treatment of polygenic disorders. Curr Sci 2004;86(8):1092-102.

2. Velavan S. Free radicals in health and diseases. Pharmacol Online 2011;1(1):1062-77.

3. Halliwell B. Antioxidants and human disease: A general introduction. Nutr Rev 1997;55:S44-9.

4. Gomberg M. An incidence of trivalent carbon trimethylphenyl. J Am Chem Soc 1900;22:757-71.

5. Inoue M, Sato EF, Nishikawa M, Park AM, Kira Y, Imada I, et al. Mitochondrial generation of reactive oxygen species and its role in aerobic life. Curr Med Chem 2003;10(23):2495-505.

6. Cadenas E, Davies KJ. Mitochondrial free radical generation, oxidative stress, and aging. Free Radic Biol Med 2000;29(3-4):222-30.

7. Valko M, Izakovic M, Mazur M, Rhodes CJ, Telser J. Role of oxygen radicals in DNA damage and cancer incidence. Mol Cell Biochem 2004;266(1-2):37-56.

8. Lopaczynski W, Zeisel SH. Antioxidants, programmed cell death, and cancer. Nutr Res 20011;21:295-307.

9. Glade MJ. The role of reactive oxygen species in health and disease northeast regional environmental public health center university of Massachusetts. Amerst Nutrition 2003;19(4):401-3.

10. Poli G, Leonarduzzi G, Biasi F, Chiarpotto E. Oxidative stress and cell signalling. Curr Med Chem 2004;11(9):1163-82.

11. Duracková Z. Some current insights into oxidative stress. Physiol Res 2010;59(4):459-69.

12. Halliwell B. Uric acid: An example of antioxidant evaluation. In: Cadenas E, Packer L, editors. Handbook of Antioxidants. New York: Marcel Dekker; 1996. p. 243-56.

13. Rahman K. Garlic and a ging: New insights into an old remedy. Ageing Res Rev 2003;2(1):39-56

14. Halliwell B, Murcia MA, Chirico S, Aruoma OI. Free radicals and antioxidants in food and in vivo: What they do and how they work. Crit Rev Food Sci Nutr 1995;35(1-2):7-20.

15. Simon HU, Haj-Yehia A, Levi-Schaffer F. Role of reactive oxygen species (ROS) in apoptosis induction. Apoptosis 2000;5(5):415-8.

16. Pierart ZC, Rozowsky NJ. Papel de la nutricion en la prevencion del cancer gastrointestinal. Rev Chil Nutr 2006;33(1):8-13.

17. Pamplona-Roger GD. Encyclopedia of Foods and Their Healing Power: A Guide to Food Science and Diet Therapy. Madrid, Spain: Editorial Safeliz; 2006. p. 447.

18. Espín JC, García-Conesa MT, Tomás-Barberán FA. Nutraceuticals: Facts and fiction. Phytochemistry 2007;68(22-24):2986-3008.

19. Shetti A, Keluskar V, Aggarwal A. Antioxidants enhancing oral and general health. J Indian Acad Oral Med Radiol 2009;21(1):1-6.

20. Reynoso-Camacho R, Ramos-Gomez M, Loarca-Pina G. Bioactive components in common beans (Phaseolus vulgaris L.) Adv Agric Food Biotechnol 2006;217-36.

21. Duarte-Martino HC, Bigonha SM, De Morais CL, De Oliveira BR, Brunoro CN, Ramirez CL, et al. Nutritional and bioactive compounds of bean: Benefits to human health. In: Tunick MH, González DE, Mejía E. editors. Hispanic Foods: Chemistry and Bioactive Compounds (ACS Symposium). USA: American Chemical Society; 2012. p. 233-58.

22. Salinas-Moreno Y, Perez-Alonso JJ, Vazquez-Carrillo G, AragonCuevas F, Velazquez-CarDelas GA. Antocianinas y actividad antioxidante en maíces (Zea mays L.) Agrociencia 2012;46(7):693-706.

23. Achakittirungrod S, Okonogi S, Poonpohn SC. Study on antioxidan activity of certain plants in Thailand: Mechanism of antioxidant action of guava leaf extract. Food Chem 2007;103(2):381-8.

24. Chaturvedi S, Sharma PK, Gark VK, Bansal M. Role of nutraceuticals in health promotion. Int J PharmTech Res 2011;3(1):442-8.

25. Kaisoon O, Siriamornpun S, Weerapreeyakul N, Meeso N. Phenolic compounds and antioxidant activities of edible flowers from Thailand. J Funct Foods 2011;3(2):88-99.

26. Chew YL, Chan EW, Tan PL, Lim YY, Stanslas J, Goh JK. Assessment of phytochemical content, polyphenolic composition, antioxidant and antibacterial activities of leguminosae medicinal plants in Peninsular Malaysia. BMC Complement Altern Med 2011;11:12.
27. Bangalore DV, McGlynn W, Scott DD. Effect of beta-cyclodextrin in improving the correlation between lycopene concentration and ORAC values. J Agric Food Chem 2005;53(6):1878-83.

28. Calliste CA, Trouillas P, Allais DP, Duroux JL. Castanea sativa mill. leaves as new sources of natural antioxidant: An electronic spin resonance study. J Agric Food Chem 2005;53(2):282-8.

29. Cerda B, Espin JC. Metabolism of antioxidants and chemopreventive ellagitanins from strawberries, raspberries, walnuts, and oak-aged wine in humans had been reported and identification of biomarkers and individual variability. J Med Food Chem 2005;68(8):1293.

30. Tachakittirungrod S, Okonogi S, Chowwanapoonpohn S. Study on antioxidant activity of certain plants in Thailand: Mechanism of antioxidant action of guava leaf extract. Food Chem 2007;103(2):381-8.

31. Chaturvedi S, Sharma PK, Garg VK, Bansal M. Role of nutraceuticals in health promotion. Int J PharmTech Res 2011;3(1):442-8.

32. Chew YL, Chan EW, Tan PL, Lim YY, Stanslas J, Goh JK. Assessment of phytochemical content, polyphenolic composition, antioxidant and antibacterial activities of Leguminosae medicinal plants in Peninsular Malaysia. BMC Complement Altern Med 2011;11(1):1-10.

33. Tuberoso CI, Boban M, Bifulco E, Budimir D, Pirisi FM. Antioxidan capacity and vasodilatory properties of mediterranean food: The case of Cannonau wine, myrtle berries liqueur and strawberry-tree honey. Food Chem 2013;140(4):686-91.

34. Kontou N, Psaltopoulou T, Panagiotakos D, Dimopoulos MA, Linos A. The mediterranean diet in cancer prevention: A review. J Med Food 2011;14(10):1065-78

35. Fernandez-Mar MI, Mateos R, Garcia-Parrilla MC, Puertas B, CantosVillar E. Bioactive compounds in wine: Resveratrol, hydroxytyrosol and melatonin: A review. Food Chem 2012;130:797-813.

36. Balasundram N, Sundaram K, Samman S. Phenolic compounds in plants and agri industrial by-products: Antioxidant activity, occurrence, and potential uses. Food Chem 2006;99:191-203.

37. Moure A, Cruz JM, Franco D, Dominguez JM, Sineiro J, Dominguez H, et al. Natural antioxidants from residual sources. Food Chem 2001;72(2):145-71.

38. Pérez-Bonilla M, Salido S, van Beek TA, Linares-Palomino PJ, Altarejos J, Nogueras $\mathrm{M}$, et al. Isolation and identification of radical scavengers in olive tree (Olea europaea) wood. J Chromatogr A 2006;1112(1-2):311-8.

39. Brian DC, Adrian LK, Ryszard A, Ronald BP. Phenol-based antioxidants and the in vitro methods used for their assessment. Compr Rev Food Sci Food Saf 2012:11:148-73.

40. Winkel-Shirley B. Flavonoid biosynthesis. A colorful model for genetics, biochemistry, cell biology, and biotechnology. Plant Physiol 2001;126(2):485-93.

41. Chouhan HS, Singh SK. Antibacterial activity of seed and flower parts of Crotalaria juncea Linn. Am Eurasian J Sci Res 2010;5(3):212-5.

42. Zhishen J, Mengcheng T, Janming W. The determination of flavonoids contents in mulberry and their scavenging effects on superoxide radicals. Food Chem 1999;64:555-9.

43. Rohman A, Riyanto S, Yuniarti N, Saputra WR, Utami R, Mulatsih W. Antioxidant activity, total phenolic, and total flavaonoid of extracts and fractions of red fruit (Pandanus conoideus Lam). Int Food Res J 2010;17:97-106.

44. Deepshikha G. Methods for determination of antioxidant capacity: A review. Int J Pharm Sci Res 2015;6(2):546-66.

45. Burda S, Oleszek W. Antioxidant and antiradical activities of flavonoids. J Agric Food Chem 2001;49(6):2774-9.

46. Inoue K, Murayarna S, Seshimo F, Takeba K, Yoshimura Y, Nakazawa H. Identification of phenolic compound in manuka honey as specific superoxide anion radical scavenger using Electron Spin Resonance (ESR) and liquid chromatography with coulometric array detection. J Sci Food Agric 2005;85:872-8.

47. Fahey JW, Stephenson KK. Pinostrobin from honey and Thai ginger (Boesenbergia pandurata): A potent flavonoid inducer of mammalian phase 2 chemoprotective and antioxidant enzymes. J Agric Food Chem 2002;50(25):7472-6.

48. Bondet V, Brand-Williams W, Berset C. Kinetics and mechanisms of antioxidant activity using the DPPH free radical method. Food Sci Technol 1997;30:609-15.

49. Parejo I, Codina C, Petrakis C, Kefalas P. Evaluation of scavenging activity assessed by $\mathrm{Co}$ (II)/EDTA-induced luminol chemiluminescence and $\mathrm{DPPH}^{*}$ (2,2-diphenyl-1-picrylhydrazyl) free radical assay. J Pharmacol Toxicol Methods 2000;44(3):507-12.

50. Ferreira IC, Aires E, Barreira JC, Estevinho LM. Antioxidant activity of Portuguese honey samples: Different contributions of the entire honey and phenolic extract. Food Chem 2009;114:1438-43. 
51. Piljac-Zegarac J, Stipcevic T, Belscak A. Antioxidant properties and phenolic content of different floral origin honeys. J Api Prod Api Med Sci 2009; $1: 43-50$.

52. Lee BC, Lee SY, Lee HJ, Sim GS, Kim JH, Kim JH, et al. Antioxidative and photo-protective effects of coumarins isolated from Fraxinus chinensis. Arch Pharm Res 2007;30(10):1293-301.

53. Jain PK, Agrawal RK. Antioxidant and free radical scavenging properties of developed mono-and polyherbal formulations. Asian J Exp Sci 2008;22(3):213-20.

54. Lavhale MS, Mishra SH. Evaluation of free radical scavenging activity of Butea monosperma Lam. Indian J Exp Biol 2007;45(4):376-84.

55. Pandey M, Sonker K, Kanoujia J, Koshy MK, Saraf SA. Sida veronicaefolia as a source of natural antioxidant. Int J Pharm Sci Drug Res 2009;1(3):180-2.

56. Cuendet M, Hostettmann K, Potterat O. Iridoid glucosides with free radical scavenging properties from Fagraea blumei. Helvetica Chimi Acta 1997;80(8):1144-52.

57. Korycka-Dahl M, Richardson M. Photogeneration of superoxide anion in serum of bovine milk and in model systems containing riboflavin and aminoacids. J Dairy Sci 1978;61:400-7.

58. Pervaiz S, Clement MV. Superoxide anion: Oncogenic reactive oxygen species? Int J Biochem Cell Biol 2007;39(7-8):1297-304.

59. Valentão P, Fernandes E, Carvalho F, Andrade PB, Seabra RM, de Lourdes Basto M. Studies on the antioxidant activity of Lippia citriodora infusion: Scavenging effect on superoxide radical, hydroxyl radical and hypochlorous acid. Biol Pharm Bull 2002;25(10):1324-7.

60. Furuno K, Akasako T, Sugihara N. The contribution of the pyrogallol moiety to the superoxide radical scavenging activity of flavonoids. Biol Pharm Bull 2002;25(1):19-23.

61. Ghiselli A, Nardini M, Baldi A, Scaccini C. Antioxidant activity of different phenolic fractions separated from an Italian red wine. J Agric Food Chem 1998;46(2):361-367.

62. Ou B, Hampsch-Woodill M, Flanagan J, Deemer EK, Prior RL, Huang D. Novel fluorometric assay for hydroxyl radical prevention capacity using fluorescein as the probe. J Agric Food Chem 2002;50(10):2772-7.

63. Ou B, Hampsch-Woodill M, Prior RL. Development and validation of an improved oxygen radical absorbance capacity assay using fluorescein as the fluorescent probe. J Agric Food Chem 2001;49(10):4619-26.

64. Beretta G, Granata P, Ferrero M, Orioli M, Facino, RM. Standardization of antioxidant properties of honey by a combination of spectrophotometric/fluorimetric assays and chemometrics. Anal Chim Acta 2005;533:185-91

65. Soares JR, Dinis TC, Cunha AP, Almeida LM. Antioxidant activities of some extracts of Thymus zygis. Free Radic Res 1997;26(5):469-78.

66. Benzie IF, Strain JJ. Ferric reducing/antioxidant power assay: Direct measure of total antioxidant activity of biological fluids and modified version for simultaneous measurement of total antioxidant power and ascorbic acid concentration. Methods Enzymol 1999;299:15-27.

67. Jerkovic I, Marijanovic Z. Oak (Ouercus frainetto Ten.) honeydew honey--approach to screening of volatile organic composition and antioxidant capacity (DPPH and FRAP assay). Molecules 2010;15(5):3744-56

68. Alvarez-Suarez JM, Tulipani S, Romandini S, Vidaland A, Battino M. Methodological aspects about determination of phenolic compounds and in vitro evaluation of antioxidant capacity in the honey. Curr Anal Chem 2009;5:293-302.

69. Huang D, Ou B, Prior RL. The chemistry behind antioxidant capacity assays. J Agric Food Chem 2005;53(6):184-56.

70. Apak R, Güçlü K, Demirata B, Ozyürek M, Celik SE, Bektasoglu B, et al. Comparative evaluation of various total antioxidant capacity assays applied to phenolic compounds with the CUPRAC assay. Molecules 2007;12(7):1496-547.

71. Schlesier K, Harwat M, Böhm V, Bitsch R. Assessment of antioxidant activity by using different in vitro methods. Free Radic Res 2002;36(2):177-87.

72. Awika JM, Rooney LW, Wu X, Prior RL, Cisneros-Zevallos L. Screening methods to measure antioxidant activity of sorghum (Sorghum bicolor) and sorghum products. J Agric Food Chem 2003;51(23):6657-62.

73. Badarinath AV, Rao KM, Chetty CM, Ramkanth S, Rajan TV, Gnanaprakash K. A review on in-vitro antioxidant methods: Comparisions, correlations and considerations. Int $\mathrm{J}$ PharmTech Res 2010;2(2):1276-85

74. Resat A, Kubilay G, Mustafa O, Esin CS. Mechanism of antioxidant capacity assays and the CUPRAC (cupric ion reducing antioxidant capacity) assay. Original Paper, Microchim Acta 2008;160:413-9.

75. Apak R, Güçlü K, Ozyürek M, Bektas Oglu B, Bener M. Cupric ion reducing antioxidant capacity assay for food antioxidants: Vitamins, polyphenolics, and flavonoids in food extracts. Methods Mol Biol 2008;477:163-93.

76. Apak R, Güçlü K, Ozyürek M, Karademir SE, Altun M. Total antioxidant capacity assay of human serum using copper(II)neocuproine as chromogenic oxidant: The CUPRAC method. Free Radic Res 2005;39(9):949-61.

77. Joana PN, Luis MM, Salette R, Jose LF, Marcela AS. High-throughput total cupric ion reducing antioxidant capacity of biological samples determined using flow injection analysis and microplate-based methods. Anal Sci 2011;27(5):483-8.

78. Apak R, Guçlu K, Birsen D, Mustafa O, Saliha EC, Burcu B. Comparative evaluation of various total antioxidant capacity assays applied to phenolic compounds with the CUPRAC assay: Review. Molecules 2007;12(7):1496-547.

79. Apak R, Güçlü K, Ozyürek M, Esin Karademir S, Erçag E. The cupric ion reducing antioxidant capacity and polyphenolic content of some herbal teas. Int J Food Sci Nutr 2006;57(5-6):292-304.

80. Lee G, Rossi MR, Coichev N, Moya HD. The reduction of $\mathrm{Cu}(\mathrm{II})$ neocuproine complexes by some polyphenols: Total polyphenols determination in wine samples. Food Chem 2011;26:679-86.

81. Folin O, Ciocalteu V. On tyrosine and tryptophane determinations in proteins. J Biol Chem 1927;73:627-50.

82. Singleton VL, Rudolf O, Lamuela-Raventos RM. Analysis of tota phenols and other oxidation substrates and antioxidants by means of folin-ciocalteu reagent. Method Enzymol 1999;299:152-78.

83. Berker KI, Ozdemir Olgun FA, Ozyurt D, Demirata B, Apak R. Modified Folin-Ciocalteu antioxidant capacity assay for measuring lipophilic antioxidants. J Agric Food Chem 2013;61(20):4783-91.

84. Kumar CS, Loh WS, Ooi CW, Quah CK, Fun HK. Structural correlation of some heterocyclic chalcone analogues and evaluation of their antioxidant potential. Molecules 2013;18(10):11996-2011.

85. Oyaizu M. Studies on products of browning reactions-antioxidative activities of products of browning reaction prepared from glucosamine. Jpn J Nutr 1986;44:307-15.

86. Verde V, Fogliano V, Ritieni A, Maiani G, Morisco F, Caporaso N. Use of N,N-dimethyl-p-phenylenediamine to evaluate the oxidative status of human plasma. Free Radic Res 2002;36(8):869-73.

87. Asghar MN, Khan IU, Arshad MN, Sherin L. Evaluation of antioxidant activity using an improved DMPD radical cation decolourization assay. Acta Chim Slov 2007;54(2):295.

88. Nathan CF, Hibbs JB. Role of nitric oxide synthesis in macrophage antimicrobial activity. Curr Opin Immunol 1991;3(1):65-70.

89. Pacher P, Beckman JS, Liaudet L. Nitric oxide and peroxynitrite in health and disease. Physiol Rev 2007;87(1):315-424.

90. Ebrahimzadeh MA, Nabavi SF, Nabavi SM. Antioxidant activities of methanol extract of Sambucus ebulus L. flower. Pak J Biol Sci 2009; $12: 447-50$.

91. Sreejayan N, Rao MN. Nitric oxide scavenging activity by curcuminoids J Pharm Pharmacol 2009;49(1):105-7.

92. Marcocci L, Maguire JJ, Droy-Lefaix MT, Packer L. The nitric oxide scavenging property of Ginkgo biloba extract EGB 761. Biochim Biophys Res Commun 1994;201(2):748-55

93. Yagi K. Simple assay for the level of total lipid peroxides in serum or plasma. Methods Mol Biol 1998;108:101-6.

94. Janero DR. Malondialdehyde and thiobarbituric acid-reactivity as diagnostic indices of lipid peroxidation and peroxidative tissue injury. Free Radic Biol Med 1990;9(6):515-40.

95. Koracevic D, Koracevic G, Djordjevic V, Andrejevic S, Cosic V. Method for the measurement of antioxidant activity in human fluids. J Clin Pathol 2001;54(5):356-61.

96. Benzie IF. Lipid peroxidation: A review of causes, consequences, measurement and dietary influences. Int $\mathrm{J}$ Food Sci Nutr 1996;47(3):233-61.

97. Cao G, Alessio HM, Cutler RG. Oxygen-radical absorbance capacity assay for antioxidants. Free Radic Biol Med 1993;14(3):303-11.

98. Rasmussen $\mathrm{CN}$, Wang $\mathrm{XH}$, Leung $\mathrm{S}$, Andrae-Nightingale LM, Schmidt SJ, Engeseth NJ. Selection and use of honey as an antioxidant in a french salad dressing system. J Agric Food Chem 2008;56(18):8650-7.

99.Gheldof N, Wang XH, Engeseth NJ. Identification and quantification of antioxidant components of honeys from various floral sources. J Agric Food Chem 2002;50(21):5870-7.

100.SAS Institute Inc. SAS Procedures Guide, Version 8. Cary, NC: SAS Institute Inc.; 1999

101.Rice-Evans CA, Miller NJ. Antioxidants-the case for fruit and vegetables in the diet. Br Food J 1995;97:35-40.

102. Salah N, Miller NJ, Paganga G, Tijburg L, Bolwell GP, Rice- 
Evans C. Polyphenolic flavanols as scavengers of aqueous phase radicals and as chain-breaking antioxidants. Arch Biochem Biophys 1995;322(2):339-46.

103.Rice-Evans CA, Miller NJ, Bolwell GP, Bramley PM, Pridham JB. The relative antioxidant activities of plant-derived polyphenolic flavonoids. Free Radic Res 1995;22(4):375-83.

104.Rice-Evans CA, Miller NJ, Paganga G. Structure-antioxidant activity relationships of flavonoids and phenolic acids. Free Radic Biol Med 1996;20(7):933-56.

105.Re R, Pellegrini N, Proteggente A, Pannala A, Yang M, Rice-Evans C. Antioxidant activity applying an improved ABTS radical cation decolorization assay. Free Radic Biol Med 1999;26(9-10):1231-7.

106.Miller NJ, Rice-Evans C, Davies MJ, Gopinathan V, Milner A. A novel method for measuring antioxidant capacity and its application to monitoring the antioxidant status in premature neonates. Clin Sci (Lond) 1993;84(4):407-12.

107.Rice-Evans C, Miller NJ. Total antioxidant status in plasma and body fluids. Methods Enzymol 1994;234:279-93.

108.Piljac-Zegarac J, Stipcevic T, Belscak A. Antioxidant properties and phenolic content of different floral origin honeys. J ApiProd ApiMed Sci 2009; $1: 43-50$

109.Rajeshwar Y, Senthil Kumar GP, Malay AG, Mazumder UK. Studies on in vitro antioxidant ativities of methanol extract of Mucuna pruriens (Fabaceae) seeds. Eur Bull Drug Res 2005;13:131-8.

110.Gupta R, Sharma M, Lakshmy R, Prabhakaran D, Reddy KS. Improved method of total antioxidant assay. Indian J Biochem Biophys 2009;46(1):126-9

111.Bors W, Michel C, Saran M. Inhibition of the bleaching of the carotenoid crocin: A rapid test for quantifying antioxidant activity. Biochim Biophys Acta 1984;796:312-9.

112.Alamdari DH, Ordoudi SA, Nenadis N, Tsimidou MZ, Koliakos G, Parizadeh SM, et al. Comparison of prooxidant-antioxidant balance method with crocin method for determination of total prooxidantantioxidant capacity. Iran J Basic Med Sci 2006;9(3, 31):158-66.

113.Manzocco L, Calligaris S, Nicoli MC. Assessment of pro-oxidant activity of foods by kinetic analysis of crocin bleaching. J Agric Food Chem 2002;50(10):2767-71

114.Bors W, Michel C, Saran M. Determination of rate constants for antioxidant activity and use of the crocin assay. Biochem Clin Appl 1992;53-63.

115.Notas G, Miliaraki N, Kampa M, Dimoulios F, Matrella E, Hatzidakis A, et al. Patients with primary biliary cirrhosis have increased serum total antioxidant capacity measured with the crocin bleaching assay. World J Gastroenterol 2005;11(27):4194-8.

116. Tubaro F, Micossi E, Ursini F. The antioxidant capacity of complex mixtures by kinetic analysis of crocin bleaching inhibition. J Am Oil Chem Soc 1996;73:173-9.

117.Pisoschi AM, Negulescu GP. Methods for total antioxidant activity determination: A review. Biochem Anal Biochem 2011;1:1-10.

118. Kunchandy E, Rao MN. Oxygen radical scavenging activity of curcumin. Int J Pharm 1990;58:237-40.

119.Esterbauer H, Cheeseman KH. Determination of aldehydic lipid peroxidation products: Malonaldehyde and 4-hydroxynonenal. Methods Enzymol 1990;186:407-21.

120.Okawa H, Ohishi N, Yagi K. Assay for lipid peroxides in animal tissues by thiobarbutiric acid reaction. Anal Biochem 1999;95(2):351-8.

121.Zhang XY. Principles of Chemical Analysis. Beijing: Chine Science Press; 2000.

122.Winston GW, Regoli F, Dugas AJ Jr, Fong JH, Blanchard KA. A rapid gas chromatographic assay for determining oxyradical scavenging capacity of antioxidants and biological fluids. Free Radic Biol Med 1998;24(3):480-93.

123.Regoli F, Winston GW. Quantification of total oxidant scavenging capacity of antioxidants for peroxynitrite, peroxyl radicals, and hydroxyl radicals. Toxicol Appl Pharmacol 1999;156(2):96-105.

124.Lichtenthäler R, Marx F. Total oxidant scavenging capacities of common European fruit and vegetable juices. J Agric Food Chem 2005;53(1):103-10.

125.Popov I, Lewin G. Antioxidative homeostasis: Characterization by means of chemiluminescent technique. Methods Enzymol 1999;300:437-56.

126.Jimenez AM, Navas MJ. Chemiluminescence methods (present and future). Grasas Aceites 2002;53:64-75.

127.Jayaprakasha GK, Singh RP, Sakariah KK. Antioxidant activity of grape seed (Vitis vinifera) extracts on peroxidation modls in vitro. Food Chem 2001;73:288-90.

128.Miller HE. A simplified method for the evaluation of anti-oxidants. J
Am Oil Chem Soc 1971;18:439-52.

129.Lee HS, Coates GA. Measurement of total vitamin C activity in citrus products by HPLC. J Liq Chromatogr Relat Technol 1999;22:2367-87.

130.Gonzalez E, Vaillant F, Rojas G, Pérez A. Novel semiautomated method for assessing in vitro cellular antioxidant activity using the light scattering properties of human erythrocytes. J Agric Food Chem 2010;58(3):1455-61.

131.Gonzalez E, Vaillant F, Pérez AM, Rojas G. In vitro cell-mediated antioxidant protection of human erythrocytes by some common tropical fruits. J Nutr Food Sci 2012;2(139):1-8.

132.Harbour JR, Chow V, Bolton JR. An electron spin resonance study of the spin adducts of $\mathrm{OH}$ and $\mathrm{HO}^{2}$ radicals with nitrones in the ultraviolet photolysis of aqueous hydrogen peroxide solutions. Can J Chem 1974;52:3549-53.

133.Prieto P, Pineda M, Aguilar M. Spectrophotometric quantification of antioxidant capacity through the formation of a phosphomolybdenum complex: Specific application to the determination of vitamin E. Anal Biochem 1999;269(2):337-41.

134.Sudha G, Priya MS, Shree RI, Vadivukkarasi S. In vitro free radical scavenging activity of raw pepino fruit (Solanum muricatum Aiton). Int J Curr Pharm Res 2011;3(2):137-40.

135. Shi X, Dalal NS, Jain AC. Antioxidant behaviour of caffeine: Efficient scavenging of hydroxyl radicals. Food Chem Toxicol 1991;29(1):1-6.

136. Weil JA, Bolton JR, Wertz JE. Electron Paramagnetic Resonance: Elementary Theory and Practical Applications. New York: John Wiley \& Sons; 1994.

137.Duling DR. Simulation of multiple isotropic spin-trap EPR spectra. J Magn Reson B 1994;104(2):105-10.

138.Mombourquette MJ, Weil JA. Fortran Program EPR NMR. Version 6.4. Saskatoon: Department of Chemistry, University of Saskatchewan; 2000.

139. Noro T, Oda Y, Miyase T, Ueno A, Fukushima S. Inhibitors of xanthine oxidase from the flowers and buds of Daphne genkwa. Chem Pharm Bull (Tokyo) 1983;31(11):3984-7.

140.Soler-Rivas C, Espin JC, Wichers HJ. An easy and fast test to compare total free radical scavenger capacity of foodstuffs. Phytochem Anal 2000;11(5):330-8.

141.Dinis TC, Maderia VM, Almeida LM. Action of phenolic derivatives (acetaminophen, salicylate, and 5-aminosalicylate) as inhibitors of membrane lipid peroxidation and as peroxyl radical scavengers. Arch Biochem Biophys 1994;315(1):161-9.

142.Jagtap UB, Panaskar SN, Bapat VA. Evaluation of antioxidant capacity and phenol content in jackfruit (Artocarpus heterophyllus Lam.) fruit pulp. Plant Foods Hum Nutr 2010;65(2):99-104.

143.Benzie IF, Strain JJ. The ferric reducing ability of plasma (FRAP) as a measure of "antioxidant power": The FRAP assay. Anal Biochem 1996;239(1):70-6.

144.Sapakal VD, Shikalgar TS, Ghadge RV, Adnaik RS, Naikwade NS, Magdum CS. In vivo screening of antioxidant profile: A review. J Herb Med Toxicol 2008;2(2):1-8.

145.Ellman GL. Tissue sulfhydryl groups. Arch Biochem Biophys 1959;82(1):70-7.

146.Paglia DE, Valentine WN. Studies on the quantitative and qualitative characterization of erythrocyte glutathione peroxidase. J Lab Clin Med 1967;70(1):158-69.

147.Yang GQ, Chen JS, Wen ZM, Ge KY, Zhu LZ, Chen XC, et al. The role of selenium in keshan disease. Adv Nutr Res 1984;6:203-31.

148. Wood JL. In: Fishman WH. editor. Metabolic Conjugation and Metabolic Hydrolysis. Vol. II. New York: Academic Press; 1970. p. 61-299.

149.Jocelyn PC. Biochemistry of the SH Group. London: Academic Press; 1972. p. 10

150.McCord JM, Fridovich I. Superoxide dismutase. An enzymic function for erythrocuprin (hemocuprein). J Biol Chem 1969;244(22):6049-55.

151.Aebi H. Catalase in vitro. Methods Enzymol 1984;105:121-6.

152.Singhal PK, Kapur N, Dhillon KS, Beamish RE, Dhalla NS. Role of free radicals in catecholamine cardiomyopathy. Can J Physiol Pharmacol 1982;60(11):1390-7.

153.Kakkar P, Das B, Viswanathan PN. A modified spectrophotometric assay of superoxide dismutase. Indian J Biochem Biophys 1984;21(2):131-2.

154.Ohkawa H, Ohishi N, Yagi K. Assay for lipid peroxides in animal tissues by thiobarbituric acid reaction. Anal Biochem 1979;95(2):351-8.

155.Buege JA, Aust SD. Microsomal lipid peroxidation. Methods Enzymol 1978;52:302-10.

156.el-Saadani M, Esterbauer H, el-Sayed M, Goher M, Nassar AY, Jürgens G. A spectrophotometric assay for lipid peroxides in serum lipoproteins using a commercially available reagent. J Lipid Res 


\section{Dontha}

1989;30(4):627-30.

157.Liu RH, Finley J. Potential cell culture models for antioxidant research.

J Agric Food Chem 2005;53(10):4311-4.
158. Wolfe KL, Liu RH. Cellular antioxidant activity (CAA) assay for assessing antioxidants, foods, and dietary supplements. J Agric Food Chem 2007;55(22):8896-907. 